\title{
Cost-Effectiveness of Energy
}

Efficiency and Renewable

Energy Technologies for

Reducing Peak Demand:

Case Study of Saudi Residential

Buildings

Moncef Krarti, Mohammad Aldubyan 


\section{About KAPSARC}

The King Abdullah Petroleum Studies and Research Center (KAPSARC) is a non-profit global institution dedicated to independent research into energy economics, policy, technology and the environment across all types of energy. KAPSARC's mandate is to advance the understanding of energy challenges and opportunities facing the world today and tomorrow, through unbiased, independent, and high-caliber research for the benefit of society. KAPSARC is located in Riyadh, Saudi Arabia.

This publication is also available in Arabic.

\section{Legal Notice}

(c) Copyright 2021 King Abdullah Petroleum Studies and Research Center ("KAPSARC"). This Document (and any information, data or materials contained therein) (the "Document") shall not be used without the proper attribution to KAPSARC. The Document shall not be reproduced, in whole or in part, without the written permission of KAPSARC. KAPSARC makes no warranty, representation or undertaking whether expressed or implied, nor does it assume any legal liability, whether direct or indirect, or responsibility for the accuracy, completeness, or usefulness of any information that is contained in the Document. Nothing in the Document constitutes or shall be implied to constitute advice, recommendation or option. The views and opinions expressed in this publication are those of the authors and do not necessarily reflect the official views or position of KAPSARC. 


\section{Key Points}

This paper proposes an optimization-based approach to evaluate the cost-effectiveness of different energy efficiency (EE) and renewable energy (RE) strategies. These strategies can reduce both the electricity consumption and the peak demand of the Saudi residential building stock.

The optimization approach is effective for identifying and designing targeted large-scale programs. Utilities and governments can deploy these programs to not only reduce the existing building stock's energy consumption but also cost-effectively lower its peak electricity demand.

This approach accounts for different building types, vintages and climate conditions to achieve the greatest benefit from large-scale programs that mix EE and RE strategies.

EE retrofit programs are the most effective for reducing both the peak demand and the annual energy consumption of the Saudi housing stock.

The cost of reducing peak demand is lower for old vintages than for new vintages of any housing type for any target energy use savings.

The optimization indicates that EE programs are highly cost-effective and significantly more appropriate for reducing peak demand within the Saudi housing stock relative to PV systems. 


\section{Summary}

$\mathrm{T}$

his paper describes an optimization-based approach to evaluate measures providing peak electricity demand reduction cost benefits for Saudi residential buildings. These measures can be categorized as energy efficiency $(E E)$ and renewable energy (RE) measures. Specifically, this paper models the existing Saudi building stock using 56 housing prototypes based on types, vintages and locations. In doing so, we present a new approach for retrofitting the existing building stock. This approach selects sets of EE and $R E$ technologies to minimize the cost of peak electricity demand reduction and maximize energy use savings. Specifically, the analysis uses the sequential search optimization technique to identify the most cost-effective combinations of EE and $R E$ actions. The approach can therefore achieve any desired cost of peak demand reduction levels with the maximum potential for energy use savings. We perform the optimization analysis for all of the housing prototypes that we model and for the entire Saudi residential building stock. This paper also evaluates a large-scale implementation of the optimal set of EE and RE packages to assess their effects on Saudi electrical load profiles. EE retrofit programs are the most effective in reducing both peak demand and annual energy consumption for the Saudi housing stock. Specifically, the analysis indicates that retrofitting the housing stock with one EE measure reduces electrical peak demand at a cost of $\$ 779$ per kilowatt $(\mathrm{kW})$. This cost is significantly lower than the estimated $\$ 22,710$ per kW for deploying rooftop PV systems. 


\section{Introduction}

everal strategies can be used to better match electricity demand with supply and improve grid reliability and resiliency. These strategies include building new power plants, establishing interconnections with other countries, developing energy storage technologies and implementing demand-side management (DSM) programs (Strbac 2008). In particular, DSM programs targeting the building sector encompass actions to manage and lower energy demand. They aim to achieve specific objectives, such as balancing supply and demand and reducing emissions (Warren 2014). Typically, demand-side load management programs include the following components (Eissa 2011):

i. Energy efficiency (EE), that is, using less energy to provide the same service.

ii. Demand response (DR), that is, influencing users' responses through incentive payments or price changes.

iii. On-site generation and storage to install cogeneration systems or renewable energy (RE) technologies, such as rooftop photovoltaic (PV) panels and batteries.

Generally, EE technologies result in long-term energy use savings, whereas DR technologies target reducing energy demand over short, critical time periods (i.e., on-peak demand periods). However, EE and DR technologies and programs may have overlapping effects. Indeed, many EE technologies reduce peak demand and, thus, have DR benefits (FERC 2019). Some examples are dimming controls for lighting systems, smart thermostats, demand ventilation controls for fresh air intake and optimal start strategies for heating and cooling equipment (Behboodi et al. 2016; Bradley, Leach, and Torriti 2013). In contrast, only some DR actions can reduce energy use and thus achieve EE effects. For instance, reducing or dimming lighting during peak periods often reduces overall energy consumption. However, on-site electricity generation often increases overall energy use. The use of pre-cooling or storage strategies to cool buildings may also increase energy consumption.

Currently, the vast majority of EE and DR programs are not coordinated and offer benefits that are specific to EE or DR but not both. In the United States (U.S.), it is estimated that only $3 \%$ of these programs combine EE and DR benefits. Of the remainder, $88 \%$ focus on $E E$, and $9 \%$ focus on DR or load management (EIA 2019; EPA 2010). In the U.S., EE programs are typically designed and administrated by state agencies or non-utility entities, whereas DR programs are managed by utilities.

The implementation of EE and DR programs often requires different business models that contractors, such as energy services companies (ESCOs), are unwilling to combine. In particular, EE programs need large amounts of capital to implement (i.e., investments in new boilers and chillers), resulting in long-term contracts. Such contracts are preferable to ESCOs. In contrast, DR programs can be deployed with low up-front investments (i.e., costs to change controls) and require short-term contracts. This business model is not usually desirable for ESCOs (EPA 2010).

Moreover, residential and small commercial buildings do not typically use dynamic rate structures, such as time-of-use or real-time pricing. These structures are usually imposed on large commercial buildings. Most building owners and operators value investments in EE projects, but they do not perceive the benefits of DR programs directly. Indeed, DR programs are seen as providing uncertain benefits or creating difficulties for building occupants. DR programs depend on incentives and 
rate structures that may easily change, require complex strategies to implement and may affect building occupants' indoor comfort levels (EPA 2010).

Gellings (1996), who first coined the term "DSM" in the 1980s, has mainly called for programs to affect magnitudes and patterns of electricity usage. These changes, in turn, affect the shape of demand and the load factor to match the supply assets' power generation (Gelazanskas and Gamage 2014). However, DSM programs have been utilized worldwide for various objectives, especially in the last decade. They are used to modernize electric power grids and make them reliable, smart and resilient. They can mitigate the impacts of climate change and increase the penetration of distributed energy resources (Alasseri et al. 2017; Bahl et al. 2017; Bergaentzlé, Clastres, and Khalfallay 2014; Harish and Kumar 2014; Ikpe and Torriti 2018; Khan 2019; Meyabadi and Deihimi 2017; Ming et al. 2013; Warren 2018). Currently, several business models and policies can be used to implement DSM programs, depending on the stakeholders involved. These stakeholders may include system operators, power generators, demand resource providers and power users, including building owners or operators (Behrangrad 2015).

Although EE does not provide dispatchable power for system operators, it can be considered a capacity resource by demand resource providers. Reducing building loads offers effectively free generating capacity. Thus, EE can compete with other power generation options in energy capacity markets through competitive bidding procedures based on the cost of demand reduction. These costs are often called 'negawatts' (Lovins 1990; PJM n.d.). In the U.S., EE programs reduced electricity use by over 28 terawatthours per year and peak demand by 8.3 gigawatts (GW) in 2018. Most of these savings were achieved by the residential sector (EIA 2019).
The total cost of implementation for these 2018 EE programs, including customer incentives and other costs, was reported to be $\$ 5.7$ billion (EIA 2019). The global market for DSM is expected to grow significantly in the next decade. Estimates suggest that it will generate up to $\$ 63.6$ billion in spending through 2028 (Navigant 2019).

The benefits of EE programs for the building sector are well documented in the literature. Their non-energy benefits, including economic, environmental and social impacts, are also well documented (IEA 2019; Krarti, Dubey, and Howarth 2019; Russell et al. 2015; WGBC 2013). Moreover, approaches for selecting EE technologies to cost-effectively reduce buildings' energy consumption, including designing and retrofitting buildings to achieve net-zero energy, are well established (Ferrara, Monetti, and Fabrizio; Krarti 2018; Lu, Wang, and Shan 2015; Wells, Rismanchi, and Aye 2018). However, limited report evaluation methods are available to determine the best EE programs to optimize the costs of reducing peak demand. A recent analysis in the U.S. estimated the costs of peak demand reduction associated with EE programs implemented in nine states (Frick et al. 2019). It found that these costs vary widely across programs, ranging from $\$ 568$ per kilowatt $(\mathrm{kW})$ in Arizona to \$2,353 per kW in Massachusetts. The average cost across all nine states was found to be $\$ 1,483$ per $\mathrm{kW}$. Moreover, the analysis estimated the average costs of peak demand reductions specific to EE programs for residential buildings. These programs included lighting upgrades ( $\$ 738$ per $\mathrm{kW}$ ) and heating, ventilating and air conditioning (HVAC) retrofitting (\$2,331 per $k W)$.

This paper introduces an optimization-based approach to minimize the cost of peak demand reduction while maximizing annual energy savings. 
This approach can help in selecting EE measures for retrofitting existing buildings. We use our approach to improve the energy performance of the residential building stock of the Kingdom of Saudi Arabia (Krarti, Aldubyan, and Williams 2020). Specifically, the optimization analysis first identifies sets of potential EE measures that lower the cost of peak demand reduction for all of the housing prototypes. Then, it determines the impacts of these optimized EE retrofits on the hourly load shapes for the Saudi residential building stock. Finally, we compare the costs of different large-scale EE retrofit scenarios with those of rooftop PV programs. We begin by providing an overview of the characteristics of Saudi electricity demand. This review highlights the levels and periods of high demand and the significant contributions of the residential sector to annual electricity consumption and peak demand. 


\section{Analysis of Saudi Electricity Demand}

0 ver the last decade, Saudi Arabia's electricity consumption initially increased owing to significant demand growth associated with the addition of new buildings and industries. It then stabilized after energy price reforms were introduced in 2016 and then declined slightly in 2018. Figure 1 illustrates these trends (Saudi Central Bank 2019).

Figure 1 also shows that the residential sector consumes the most electricity in Saudi Arabia. However, this sector's contribution has declined from
$50.4 \%$ in 2015 to $44.9 \%$ in 2018. Indeed, from 2015 to 2018 , electricity consumption decreased more significantly in the Saudi housing sector than in any other sector, as Figure 2 shows. Specifically, only the residential sector saw its energy consumption fall by $10 \%$ during this period. In contrast, the other sectors maintained or increased their electricity consumption during that period. This decrease in residential energy use most likely resulted from behavioral changes after the energy price reforms of 2016 and 2018. The housing stock actually increased from 2015 to 2018 (GaStat 2018).

Figure 1. Saudi Arabia's annual electricity consumption by sector from 2005 through 2018.

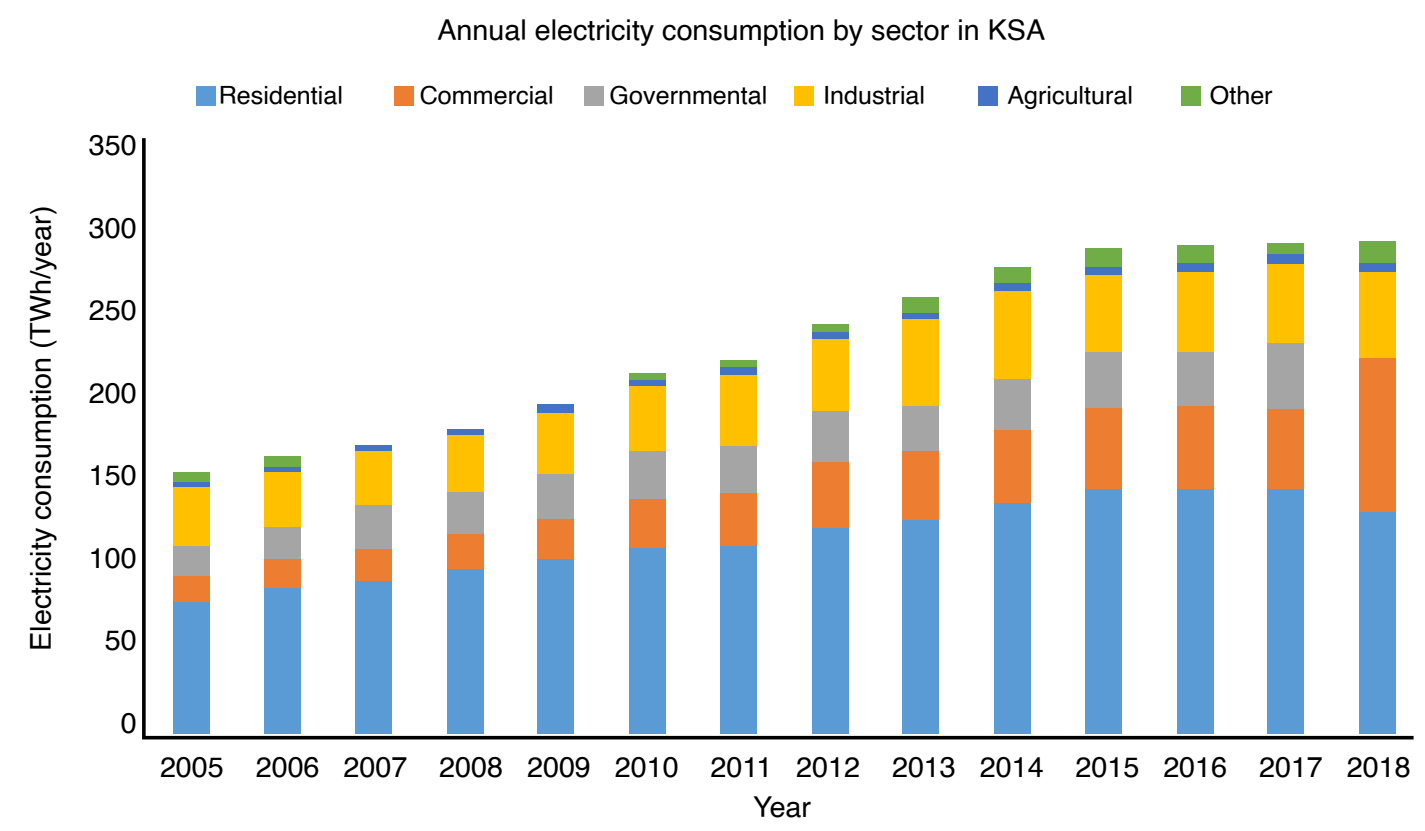

Source: Saudi Central Bank 2019

Figure 3 shows that Saudi Arabia's overall peak electricity demand declined after 2015 even though the number of subscribers to the grid steadily increased (WERA 2020a). From 2005 to 2018, peak demand reached a maximum of 63,000 megawatts (MW) in 2015. It fell to 60,800 MW in 2016 and then stabilized at 62,000 MW in 2017 and 2018. Saudi
Arabia's peak electricity demand occurs during the summer, when air conditioning needs are significant. The hourly electricity load profiles of Saudi Arabia for 2015 for the Saudi Electricity Company's (SEC's) Eastern, Western, Central and Southern operating regions clearly exhibit this pattern (SEC 2015). Specifically, peak demand occurred on July 22 in 
the Western region, July 23 in the Southern region and July 29 in the Eastern and Central regions. Saudi Arabia's overall peak electricity demand occurred on July 29 at 3 p.m. Figure 5 presents the hourly load duration curve for Saudi Arabia in 2015 and indicates a peak demand of 60,118 MW.

Figure 2. Percent change in annual Saudi electricity consumption by sector relative to 2005 .

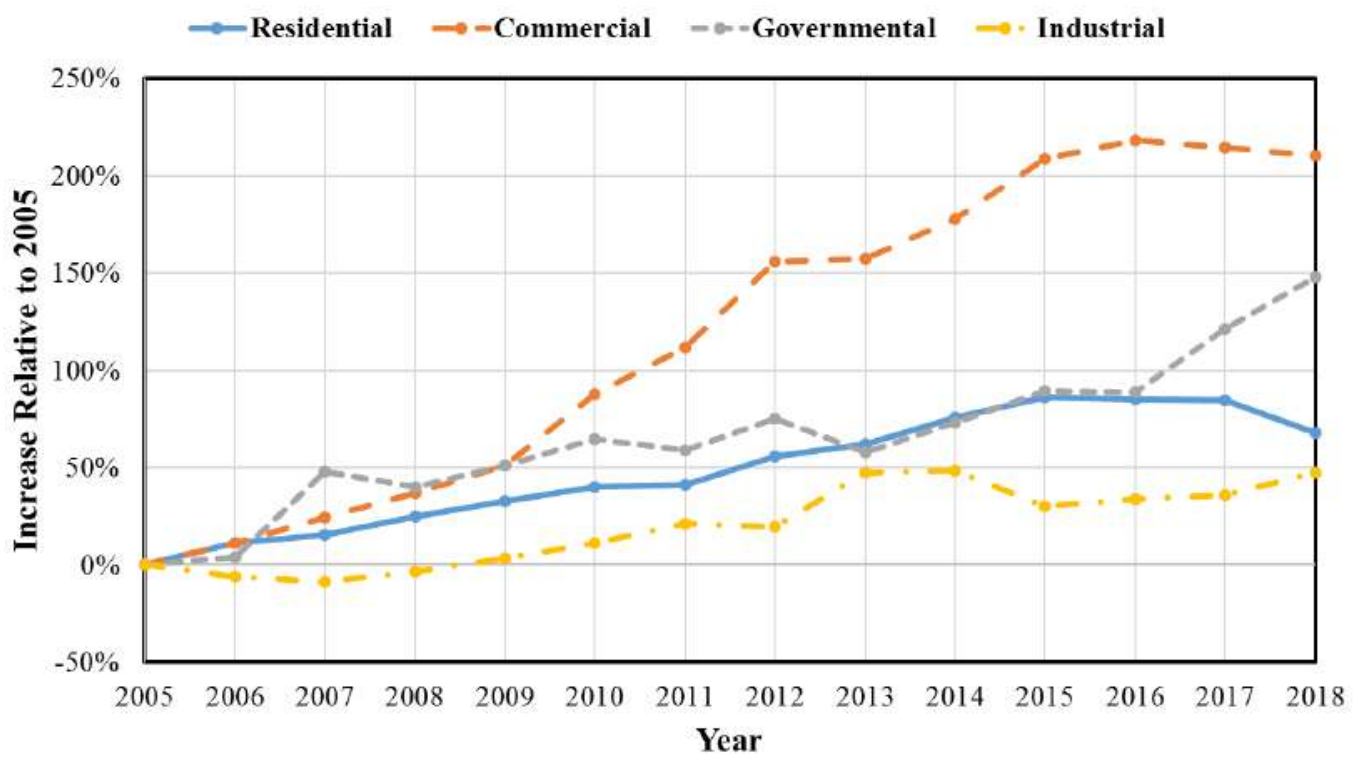

Source: Saudi Central Bank 2019.

Figure 3. The Saudi grid's annual peak electricity demand and number of subscribers from 2005 to 2018.

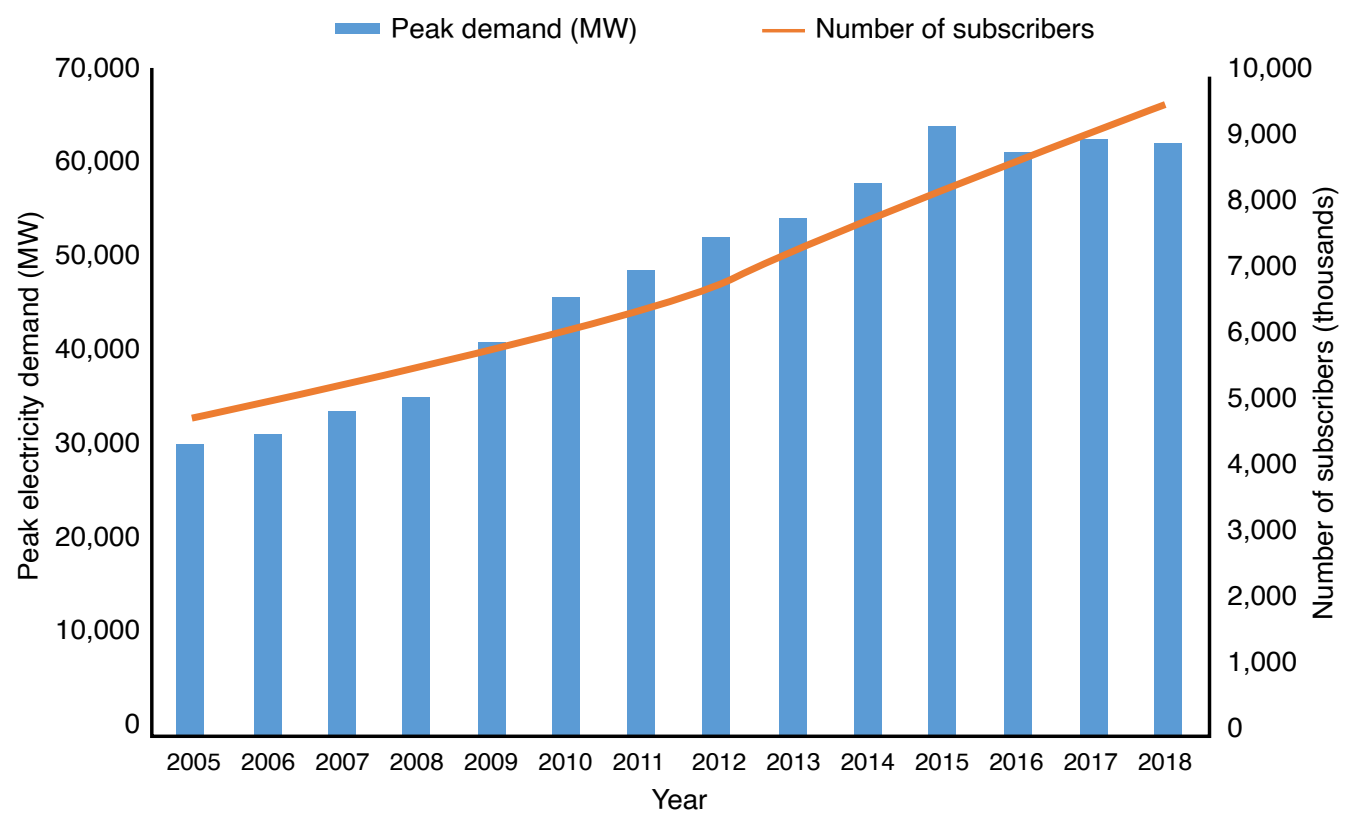

Source: WERA 2020a 
Figure 4. Hourly electricity demand profiles for the four Saudi regions in 2015.

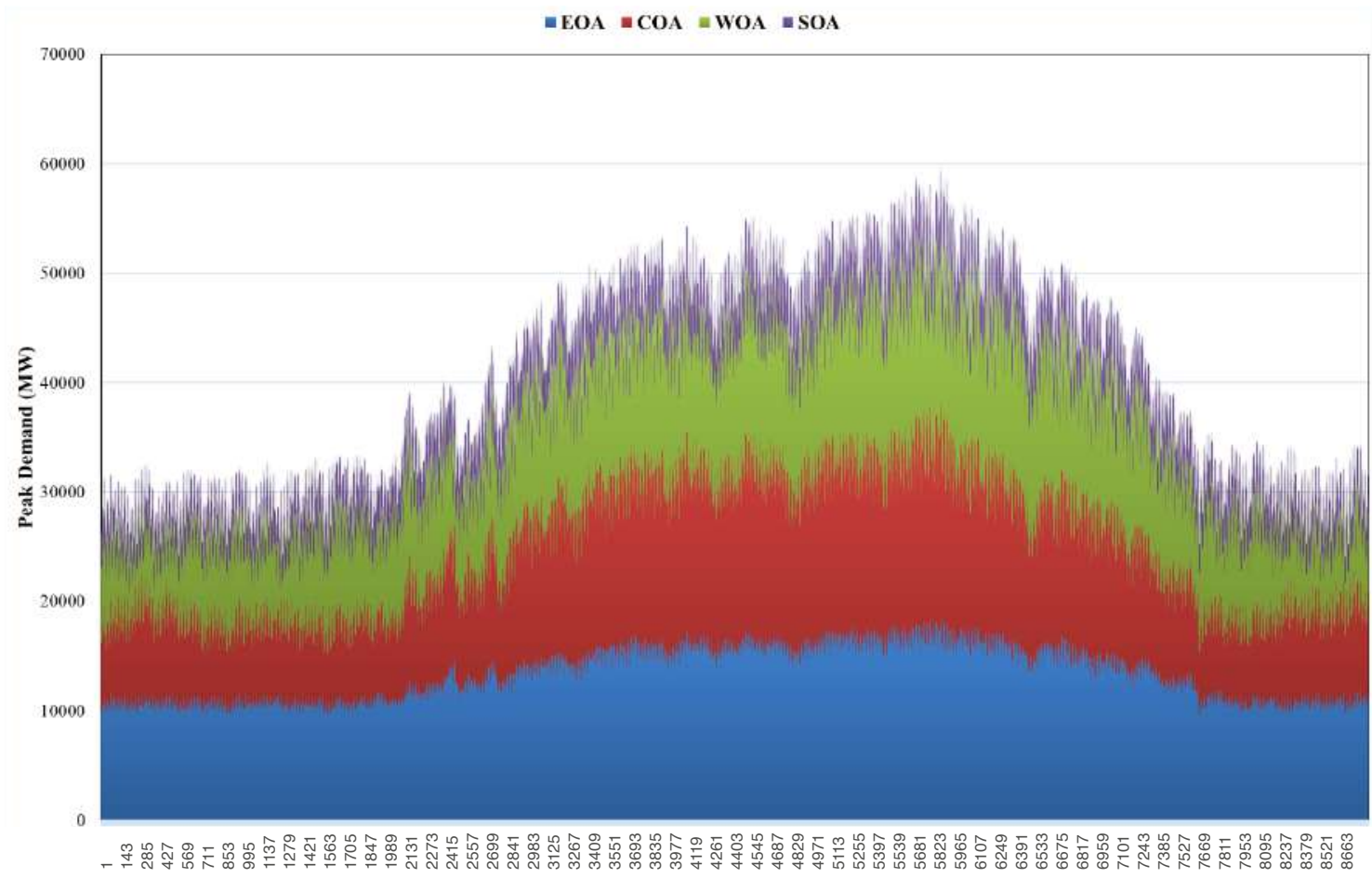

Source: SEC 2015.

Figure 5. Hourly cumulative frequency distribution of electricity demand by region and for Saudi Arabia in 2015.

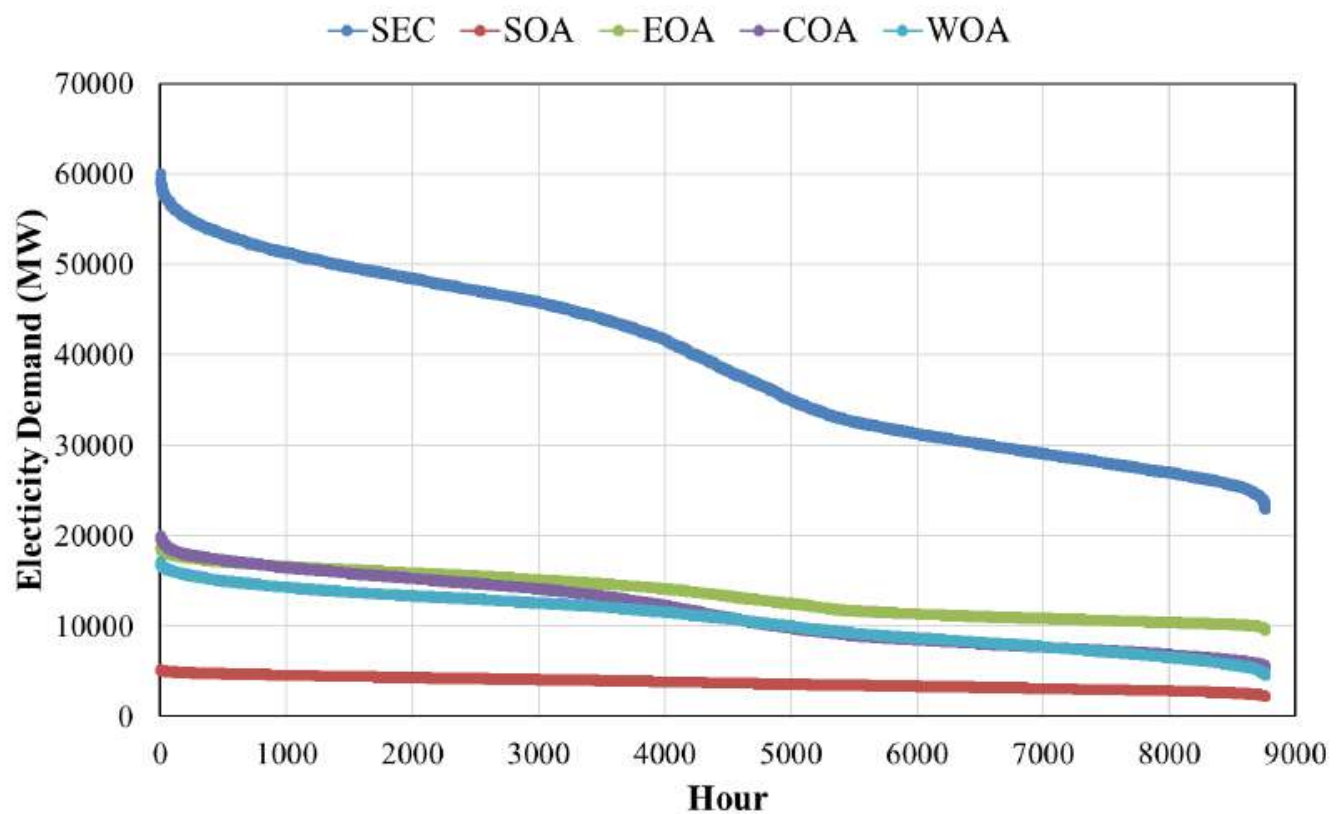

Source: SEC 2015. 
Table 1 summarizes the main characteristics of the load profiles for the four Saudi regions and the overall electrical system in 2015 . The peak demand and the average load clearly differ in all regions. The peak demands for each region occur for only a limited number of hours, and the load factors range from 0.58 to 0.72 . The differences between the peak demand and the average load are particularly large for the Central and Western regions, resulting in low load factors.

These low load factors, shown in Table 1, present opportunities for DSM programs. Specifically, well-targeted DSM measures that are applied for only 63 hours per year can reduce peak demand by $5 \%$. More aggressive DSM actions covering 367 hours of the year can lower peak demand by $10 \%$, resulting in a new peak below $54,000 \mathrm{MW}$. The Central and Western regions are the best locations for DSM programs. As Table 1 shows, these regions have the lowest load factors and the highest peak demand-to-baseload ratios. The Southern region has rather low electricity demand owing to its sparse population and its varying climates. Some locations (i.e., Abha) require substantial heating, whereas others (i.e., Jazan) need only air conditioning.

Table 1. Main characteristics of the 2015 electricity load profiles for Saudi Arabia.

\begin{tabular}{|c|c|c|c|c|c|}
\hline Metric & Eastern & Central & Western & Southern & Total \\
\hline Peak demand (MW) & 18,578 & 19,769 & 17,102 & 5,046 & 60,118 \\
\hline Average load (MW) & 13,376 & 11,466 & 10,603 & 3,633 & 39,077 \\
\hline Load factor & 0.72 & 0.58 & 0.62 & 0.72 & 0.65 \\
\hline $\begin{array}{l}\text { Peak demand to baseload } \\
\text { ratio }\end{array}$ & 1.95 & 3.77 & 3.82 & 2.41 & 2.62 \\
\hline $\begin{array}{l}\text { Number of hours with a load } \\
\text { above } 95 \% \text { of the peak load }\end{array}$ & 149 & 60 & 60 & 157 & 63 \\
\hline $\begin{array}{l}\text { Number of hours with a load } \\
\text { above } 90 \% \text { of the peak load }\end{array}$ & 796 & 281 & 325 & 751 & 367 \\
\hline
\end{tabular}

Source: SEC 2015 


\section{Analysis Methodology}

$\mathrm{T}$ The aim of the analysis in this study is to assess EE measures. Optimal EE measures should reduce both peak demand and annual energy consumption for the existing Saudi housing stock. Specifically, this paper's analysis proceeds in three steps:

i. It defines housing prototypes to represent the residential building stock.

ii. It performs an optimization analysis to select a set of EE measures. These measures should cost-effectively reduce electricity demand, maximize energy savings and maintain indoor thermal comfort.

iii. It assesses the impacts of the optimal EE sets on the overall grid load profile, including peak demand and load factors, for various Saudi regions and the entire network. The costs and benefits of the large-scale implementation of the optimal EE sets and various rooftop PV systems are also evaluated.
In the following subsections, we outline the analytical approach, including the building stock model and the optimization technique.

\section{Housing stock prototypes}

As Krarti, Aldubyan, and Williams (2020) describe, the existing Saudi residential building stock can be modeled using 54 housing unit prototypes. These prototypes are defined by three characteristics: type, vintage and location. We briefly outline these characteristics below.

(i) Type includes three categories: villas, apartment units and traditional houses. Table 2 summarizes the main features of the Saudi housing prototypes. Figure 6 provides renderings of the energy models of the three housing prototypes.

Table 2. Main specifications for the three Saudi housing prototypes.

\begin{tabular}{l|l|l|l} 
Building model & Villa & Apartment unit & Traditional house \\
\hline Number of floors & 2 & 3 & $1,260 \mathrm{~m}^{2}$ \\
\hline Total floor area & $525 \mathrm{~m}^{2}$ & $20 \mathrm{~mm}$ plaster outside $+150 \mathrm{~mm}$ concrete hollow block $+20 \mathrm{~mm}$ plaster inside \\
\hline Wall construction & $10 \mathrm{~mm}$ built-up roofing $+200 \mathrm{~mm}$ concrete roof slab $+13 \mathrm{~mm}$ plaster inside \\
\hline Roof construction & Ceramic tile $+100 \mathrm{~mm}$ concrete slab on grade & 232 \\
\hline Floor construction & Single-clear with wood frames & $15 \%$ \\
\hline Glazing & $13 \%$ & $15 \%$
\end{tabular}




\begin{tabular}{l|l|l|l} 
Infiltration & $0.8 \mathrm{ACH}$ & $0.8 \mathrm{ACH}$ & $0.8 \mathrm{ACH}$ \\
\hline Cooling set point & $23^{\circ} \mathrm{C}$ & $24^{\circ} \mathrm{C}$ & $24^{\circ} \mathrm{C}$ \\
\hline HVAC system & Split DX & AC Window & AC Window \\
\hline Energy efficiency ratio (EER) & 7.5 & 8.5 & 8.5 \\
\hline Occupancy period & 24 hours/day & 24 hours/day & 24 hours/day
\end{tabular}

Note: $\mathrm{m}^{2}=$ meters squared; $\mathrm{mm}=$ millimeters; $\mathrm{ACH}=$ air change per hour; $\mathrm{DX}=$ direct expansion cooling; ${ }^{\circ} \mathrm{C}=$ degrees $\mathrm{Celsius}$.

Figure 6: Renderings of energy models for (a) a villa, (b) an apartment and (c) a traditional house.

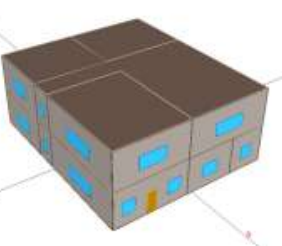

(a)

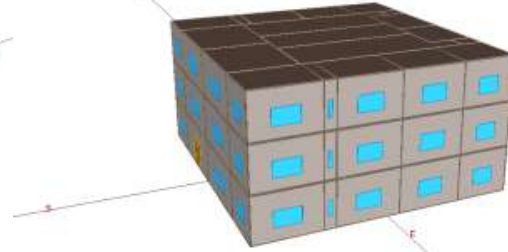

(b)

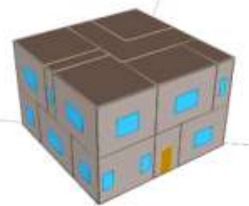

(c)

Source: Authors.

(ii) Vintage depends on the construction year of a housing unit and includes new construction, recently built housing, and old buildings. New (N) construction is typically less than five years old and has wall and roof insulation and double glazed windows. Recently $(R)$ built housing is $5-10$ years old and includes only thermal insulation in the walls and roof. Old $(\mathrm{O})$ buildings were constructed more than 10 years ago, have no thermal insulation and have only single glazed windows. (iii) Location accounts for both climatic conditions and the SEC's administrative regions. Six locations are considered in this study: Jeddah, Riyadh, Dhahran, Abha, Jazan and Tabuk.

\section{Description of EE measures}

The optimization analysis considers both roof PV systems and a set of proven EE measures. We assess their abilities to reduce both peak demand and energy use. Table 3 lists the specific EE and RE measures evaluated in this study. 
Table 3. EE and RE measures evaluated for Saudi residential building prototypes.

\begin{tabular}{|c|c|c|}
\hline Retrofit category & Specifications & Measures \\
\hline Exterior walls & Add wall insulation & $\begin{array}{l}\text { RSI-1.5 polystyrene }(50 \mathrm{~mm}) \\
\text { RSI-3.0 polystyrene }(100 \mathrm{~mm})\end{array}$ \\
\hline Roofs & Add roof insulation & $\begin{array}{l}\text { RSI-1.5 polystyrene }(50 \mathrm{~mm}) \\
\text { RSI-3.0 polystyrene }(100 \mathrm{~mm})\end{array}$ \\
\hline Windows & Replace window glazing & $\begin{array}{l}\text { Double clear }\left(6 / 6 / 6 \mathrm{~mm}, \mathrm{U}: 3.163 \mathrm{~W} / \mathrm{m}^{\left.2 .{ }^{\circ} \mathrm{C}\right)}\right. \\
\text { Double low-e }\left(6 / 12 / 6 \mathrm{~mm}, \mathrm{U}: 1.658 \mathrm{~W} / \mathrm{m}^{2 .}{ }^{\circ} \mathrm{C}\right)\end{array}$ \\
\hline Overhang & Add shading devices above the windows & $\begin{array}{l}0.5 \mathrm{~m} \text { overhang } \\
1.0 \mathrm{~m} \text { overhang }\end{array}$ \\
\hline Lighting & Use light-emitting diodes and improve operation & $\begin{array}{l}50 \% \text { reduction } \\
70 \% \text { reduction }\end{array}$ \\
\hline Air infiltration & Reduce air leakage & $\begin{array}{l}50 \% \text { reduction } \\
75 \% \text { reduction }\end{array}$ \\
\hline Appliances & Electricity consumption level & $\begin{array}{l}\text { Class } 3: 30 \% \text { reduction } \\
\text { Class } 1: 65 \% \text { reduction }\end{array}$ \\
\hline Air conditioner & EER & $\begin{array}{l}10.0 \\
12.0 \\
\end{array}$ \\
\hline Cool roof & Use highly reflective coatings on roofs & $\mathrm{SR}=0.6$ \\
\hline Roof PV & Size depends on available roof area & Rated efficiency $=14.8 \%$ \\
\hline
\end{tabular}

Note: Insulation R-values are expressed in $\mathrm{RSI}\left(\mathrm{m}^{2} .{ }^{\circ} \mathrm{C} / \mathrm{W}\right)$ and $\mathrm{R}\left(\mathrm{hr}_{\mathrm{ft}} \mathrm{ft}^{\circ}{ }^{\circ} \mathrm{F} / \mathrm{Btu}\right) ; \mathrm{SR}=$ solar reflectance

The implementation capital costs of the EE measures listed in Table 3 are estimated from various sources (Alaidroos and Krarti 2015; Krarti 2015; Krarti, Dubey, and Howarth 2017). The capital costs for the three housing prototypes outlined in
Figure 4 are listed in Table 4. They are based on the geometric dimensions of each housing prototype and the EE measure and are independent of the location. 
Table 4. Implementation costs (\$) for various EE measures for the three housing prototypes.

\begin{tabular}{|c|c|c|c|}
\hline EE Measure & Traditional house & Villa & Apartment \\
\hline $\mathrm{R}-8$ walls & 4,369 & 6,737 & 12,498 \\
\hline $\mathrm{R}-18$ walls & 8,429 & 12,996 & 24,111 \\
\hline R-8 roof & 1,853 & 4194 & 6,711 \\
\hline R-18 roof & 3707 & 8388 & 13,421 \\
\hline Double-clear & 8,542 & 11,449 & 24,435 \\
\hline Double-low-e & 12,913 & 17,307 & 36,937 \\
\hline Overhang-0.5 & 2,706 & 3,627 & 7,740 \\
\hline Overhang-1.0 & 5,412 & 7,254 & 15,481 \\
\hline Infilt-50\% & 511 & 809 & 1,940 \\
\hline Infilt-70\% & 767 & 1,213 & 2,911 \\
\hline Light-50\% & 248 & 393 & 942 \\
\hline Light-70\% & 321 & 508 & 1,220 \\
\hline Equip-30\% & 2,096 & 3,493 & 4,191 \\
\hline Equip-65\% & 2,574 & 4,290 & 5,148 \\
\hline AC-EER-10 & 3,564 & 5940 & 7,128 \\
\hline AC-EER-12 & 3,795 & 6,325 & 7,590 \\
\hline Cool-roof & 2,320 & 5,250 & 8,400 \\
\hline $\begin{array}{l}\text { Roof-PV* } \\
\text { (maximal capacity) }\end{array}$ & 18,000 & 39,000 & 63,000 \\
\hline
\end{tabular}

${ }^{(*)}$ Note: The PV system cost is assumed to be $\$ 3,000$ per kW. The maximum capacities are $6 \mathrm{~kW}$ for a traditional house, $13 \mathrm{~kW}$ for a villa and $21 \mathrm{~kW}$ for an apartment. These values are based on the available roof areas. Infilt = infiltration; equip = equipment.

Source: Authors. 


\section{Optimization analysis}

As noted earlier, this study's main goal is to determine the best set of EE measures to be implemented for housing units. The aim is to reduce their peak electricity demand and their annual energy consumption. To determine how to achieve this target, we carry out an optimization analysis. The goal is to minimize the electricity demand reduction cost, $C_{d}$, from the application of any EE measure.

$$
C_{d}=\min _{\text {all } i}\left[\frac{C_{E E}}{E_{b, i}-E_{E E, i}}\right],
$$

where

$C_{E E}$ is the implementation cost of a set of EE measures
$E_{b, i}$ is the baseline electricity demand in hour $i$

$E_{E E, i}$ is the electricity demand in hour $i$ after the EE measures are implemented.

The implementation cost is set for each EE measure. Thus, the optimization cost function of Eq. (1) effectively implies that the main objective is to maximize demand reduction. Figure 7 illustrates the estimated hourly demand reduction $\left(E_{b, i}-E_{E E, i}\right)$ between the baseline load profile and the modified housing unit load profile. The modified load profile results from the implementation of a set of EE or RE measures. Importantly, estimating the maximal demand reduction requires the hourly load profiles for both baseline and retrofitted housing units. For Saudi housing units, the maximal demand reduction generally occurs when the air conditioning load is at its highest.

Figure 7. Estimated maximal demand reduction across the baseline and modified load profiles.

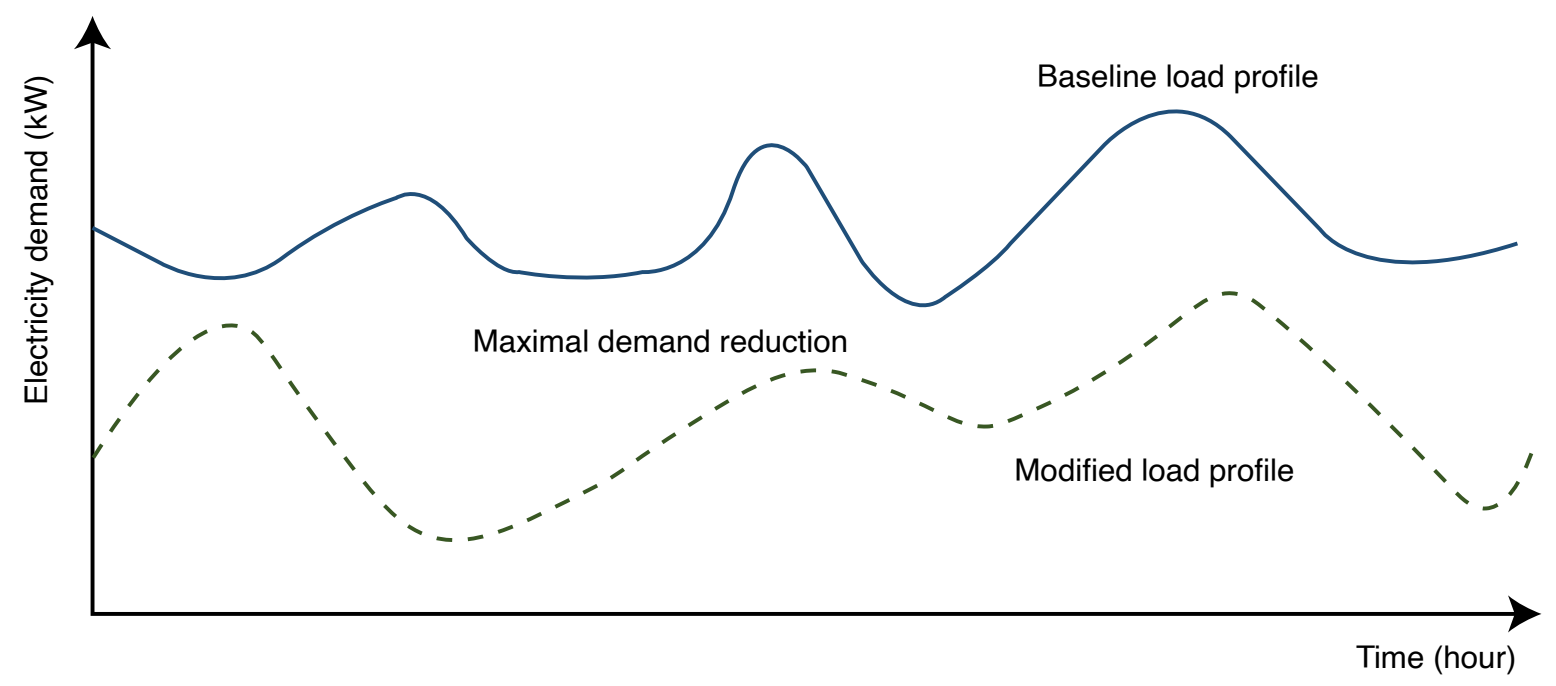

Source: Authors. 
The optimization method used in this study is the sequential search technique. This technique has been utilized in a wide range of building $E E$ applications (Christensen, Barker, and Horowitz 2004; Krarti and Deneuville 2015; Griego, Krarti, and Hernandez-Guerrero 2015; Ihm and Krarti 2012; Krarti 2012; Tuhus-Dubrow and Krarti 2009). This study's main objective is to identify the best EE measures to reduce electricity demand at the lowest cost. However, it is also important to ensure that the change in energy consumption does not affect indoor thermal comfort. Specifically, we aim to both minimize the demand reduction cost defined in Eq. (1) and maximize the annual energy savings given by Eq. (2):

$\Delta E=\max \left\{\sum_{i}\left(E_{b, i}-E_{E E, i}\right)\right\}$.

Thus, the optimization has two objectives. The sequential search technique is suitable for a multi-objective optimization problem. It enables the effective determination of the optimal path with reduced computational efforts, as the Pareto diagram in Figure 8 shows. This technique identifies the optimal path through an iterative procedure. First, all of the EE measures are evaluated individually to determine their demand reduction costs (i.e., $C_{d}$ ) and energy savings (i.e., $\Delta E)$. The EE measure that provides the lowest $\mathrm{C}_{\mathrm{d}}$ value with the maximum energy savings is the measure with the lowest $C_{d}$ to $\Delta E$ ratio. Then, the modified housing unit with that $E E$ measure becomes the new baseline. The next best $E E$ measure is then identified using the same procedure until all of the EE measures are exhausted.

Once the optimal path is determined, the set of EE measures that provides the lowest demand reduction cost can be determined based on the desired EE target. Figure 8 illustrates this process. Especially for Saudi buildings with high air conditioning loads, the reduction in energy consumption is an indicator of the reduction in peak electricity demand. However, assessing the full impact of the optimal set of EE measures on peak demand requires knowing the modified load profile for each housing unit. This process is discussed in the results section.

Figure 8. Sequential search technique to determine the optimal Pareto path.

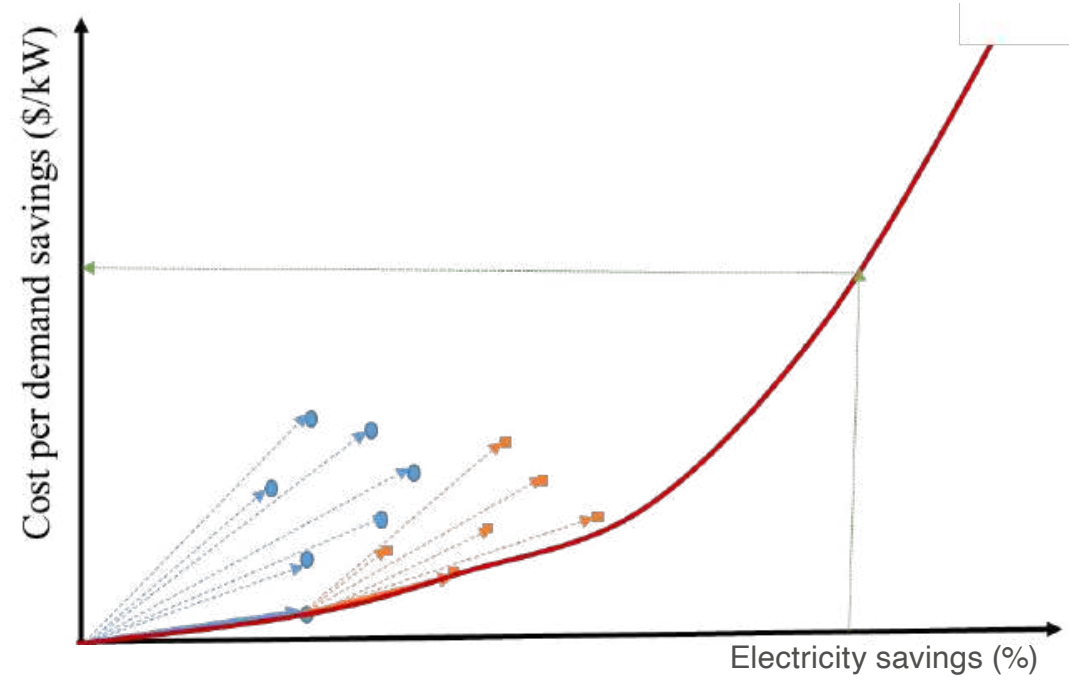

Source: Authors. 


\section{Discussion of the Analysis Results}

$\mathrm{T}$ This section presents some representative analysis results to provide insights on the benefits of EE measures, including rooftop PV systems. We consider reductions in both peak electricity demand and energy consumption for various housing types and climatic conditions.

\section{Impact of EE and RE measures on individual housing units}

Recently, Saudi Arabia approved a regulatory framework for small-scale solar distribution systems to be connected to the power grid (WERA 2020b). Although this framework has not yet been enacted, it allows for the introduction of the net metering concept using a net-billing mechanism. This mechanism can credit PV-generated electricity exported to the grid at set rates. For instance, households are credited 0.07 riyals per kilowatthour (kWh) (\$0.0187 per kWh) for any excess electricity generated by rooftop PV systems. Thus, properly selecting a PV system is important to optimize its cost-effectiveness.
Figure 9 illustrates the impact of a rooftop PV system relative to that of wall and roof insulation on a traditional Riyadh house's load profile. We consider both a winter day (Figure 9[a]) and a summer day (Figure 9[b]). As Figure 9(a) shows, the electricity generated by the PV system slightly exceeds the house's needs from 11 a.m. to 3 p.m. on a winter day. The peak demand at 7 a.m. is unchanged owing to heating requirements. However, the application of thermal insulation in the walls and roof significantly reduces heating demand. Thus, the peak demand that occurs in the morning owing to space heating needs is also reduced.

During the summer, the electricity produced by the PV system helps to reduce demand during the day (9 a.m. to 5 p.m.). It also lowers demand during the late afternoon, with peak demand occurring around 6-7 p.m. Conversely, the thermal envelope improvements significantly reduce the hourly electrical demand. The reduction in space cooling needs not only lowers peak demand but also provides a more uniform load profile than does a PV system.

Figure 9. Load profiles with the addition of a rooftop PV system and the improvement of the building envelope for a traditional house in Riyadh on (a) a winter day and (b) a summer day.

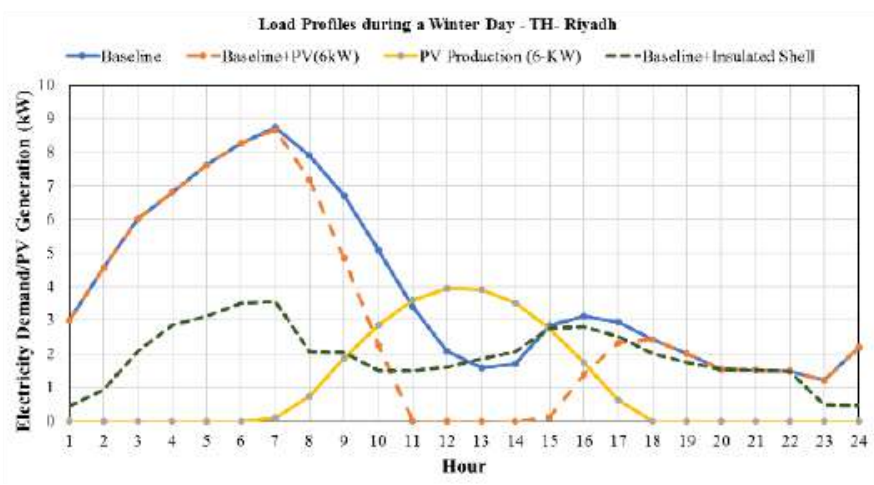

(a)

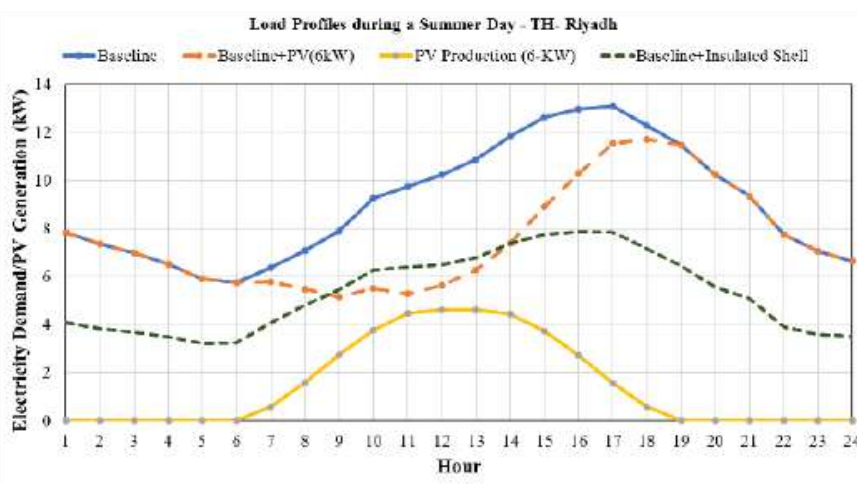

(b)

Source: Authors. 
Table 5 summarizes the main features of the hourly load profiles for the three design options for a traditional house. The addition of thermal insulation not only reduces both energy use and peak demand but also slightly improves the load factor. Thus, it results in a more uniform electrical load. It increases the number of hours that the load exceeds $90 \%$ of peak demand from 105 hours to 141 hours. In contrast, the integration of a rooftop PV system reduces both peak demand and the load factor. The number of hours when the load is above $90 \%$ of peak demand falls to just 77 .

Table 5. Impacts of an EE measure and a rooftop PV system on the electrical load features of a house in Riyadh.

\begin{tabular}{l|l|l|l} 
Metric & Baseline & Integrated rooftop PV system & Insulated building envelope \\
\hline Average load $(\mathrm{kW})$ & 4.97 & 3.84 & 3.13 \\
\hline Load factor & 0.37 & 0.31 & 0.38 \\
\hline Peak demand $(\mathrm{kW})$ & 13.47 & 12.43 & 8.25 \\
\hline Number of hours with load above 95\% of peak & 26 & 15 & 24 \\
\hline Number of hours with load above 90\% of peak & 105 & 77 & 141
\end{tabular}

Source: Authors.

Figure 10 compares the load duration curves (i.e., cumulative frequency curves) for a baseline traditional house in Riyadh. We consider the integration of a rooftop PV system and retrofitting with wall and roof insulation. The addition of thermal insulation to the building envelope clearly has a more dramatic impact on the house load curve than the PV system does. 
Figure 10. Load duration curves for baseline, PV-integrated and insulated traditional houses in Riyadh.

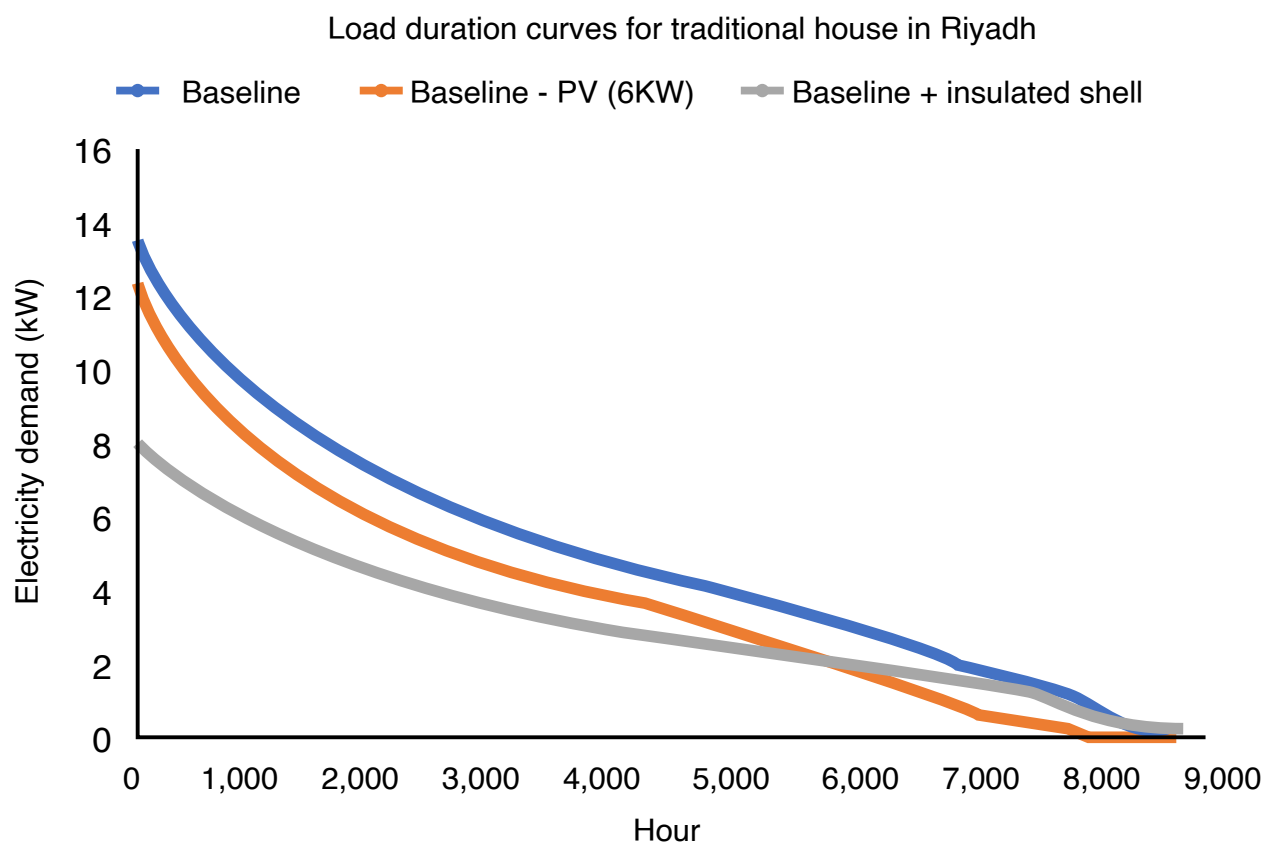

Source: Authors.

Hour

\section{Optimal EE measures}

Figure 11 shows the optimization results using the sequential search technique for the old and new prototypes of a traditional house in Riyadh. We consider the set of EE measures listed in Table 3. We aim to minimize the cost of electricity demand reduction defined by Eq. (1) and maximize the annual energy use savings given by Eq. (2). The solid line in Figure 11 shows the minimum cost of demand reduction as a function of annual energy savings. This cost is expressed as a percentage of the baseline case.

As expected, as the energy savings increase, the cost to reduce demand increases for both prototypes. Reductions in both demand and energy use are more costly to achieve for the new vintage than for the old vintage. For instance, a $40 \%$ reduction in the annual energy consumption of an old traditional house costs $\$ 1,000$ per $\mathrm{kW}$ of demand reduction. The same energy use reduction requires an investment of $\$ 2,000$ per $\mathrm{kW}$ for the new vintage. Interestingly, based on an installation cost of $\$ 3,000$ per $\mathrm{kW}$, a PV rooftop system is only cost-competitive with other EE measures in narrow circumstances. The energy generated must provide at least $70 \%$ and $50 \%$ of total consumption for the old and new vintages, respectively, of the traditional Riyadh house. However, Table 5 shows that the rooftop PV system at its maximum capacity of 6 $\mathrm{kW}$ reduces annual energy consumption by only $22.7 \%$. Moreover, it does not significantly affect peak demand. At this level, the optimal set of EE measures costs less than $\$ 1,000$ per $\mathrm{kW}$, as shown by the optimal path of Figure 11(a).

We obtain similar findings for other locations and housing types. Figure 12 shows the results for old, recent and new traditional houses in Abha. Figure 13 shows the results for all vintages of the villa and apartment prototypes in Riyadh. 
Figure 11. Optimization results for the (a) old, (b) recent and (c) new vintages of traditional houses in Riyadh.

(a)
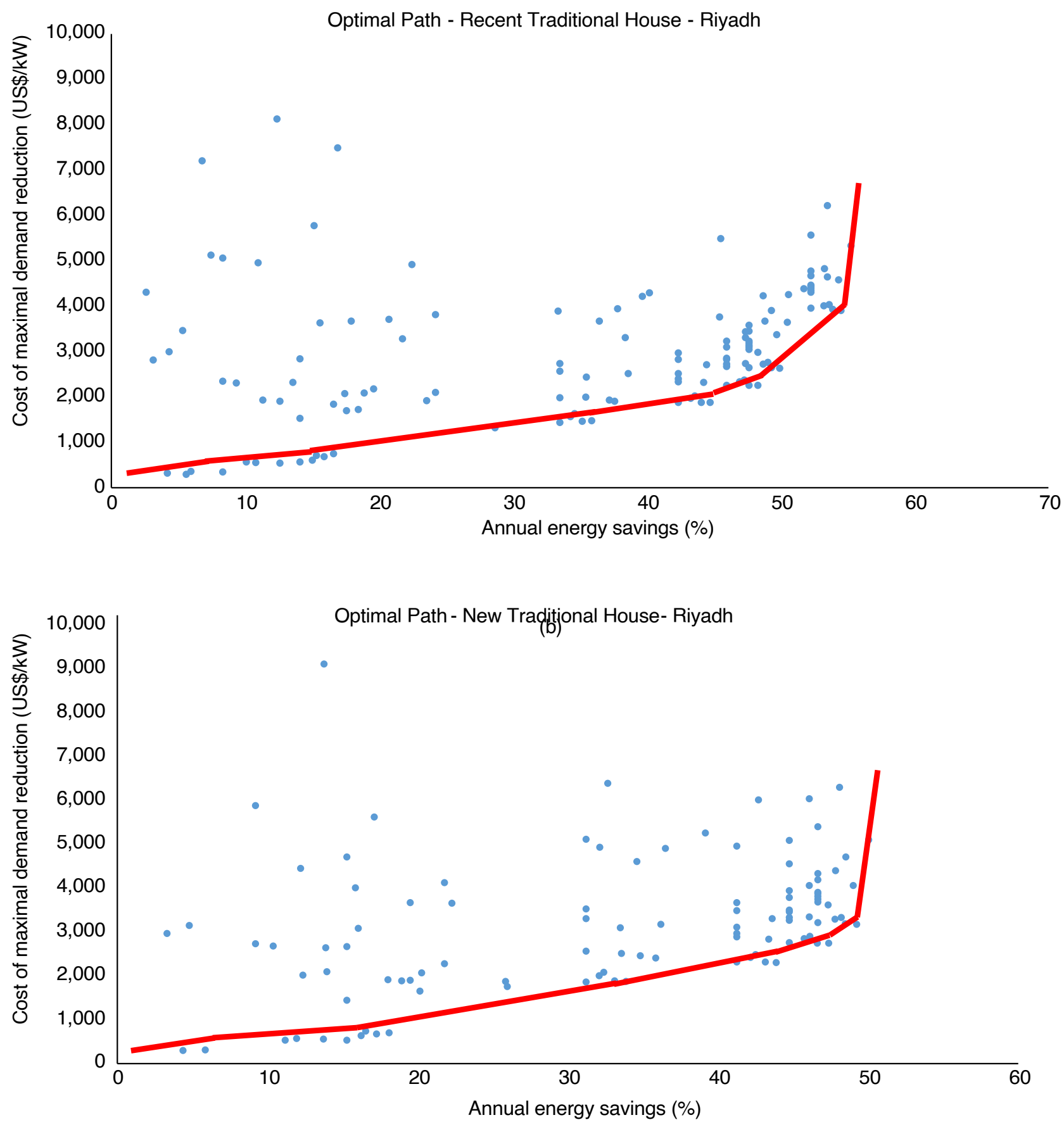

Source: Authors. 
Figure 12. Optimization results for the (a) old, (b) recent and (c) new vintages of traditional houses in Abha.
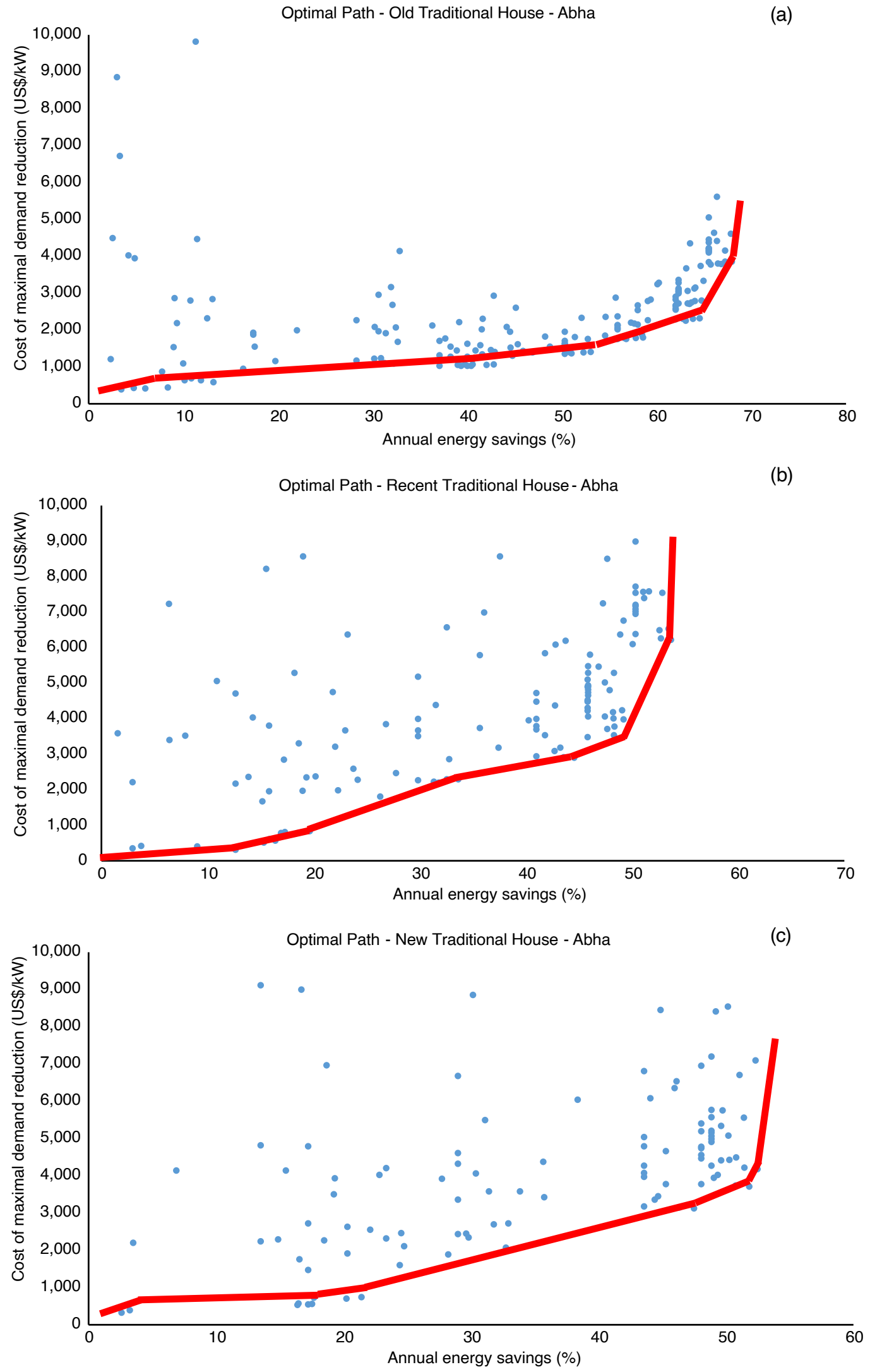

Source: Authors. 
Figure 13. Optimization results for the (a) old, (b) recent and (c) new vintages of both the villa and the apartment prototypes in Riyadh.

(a)
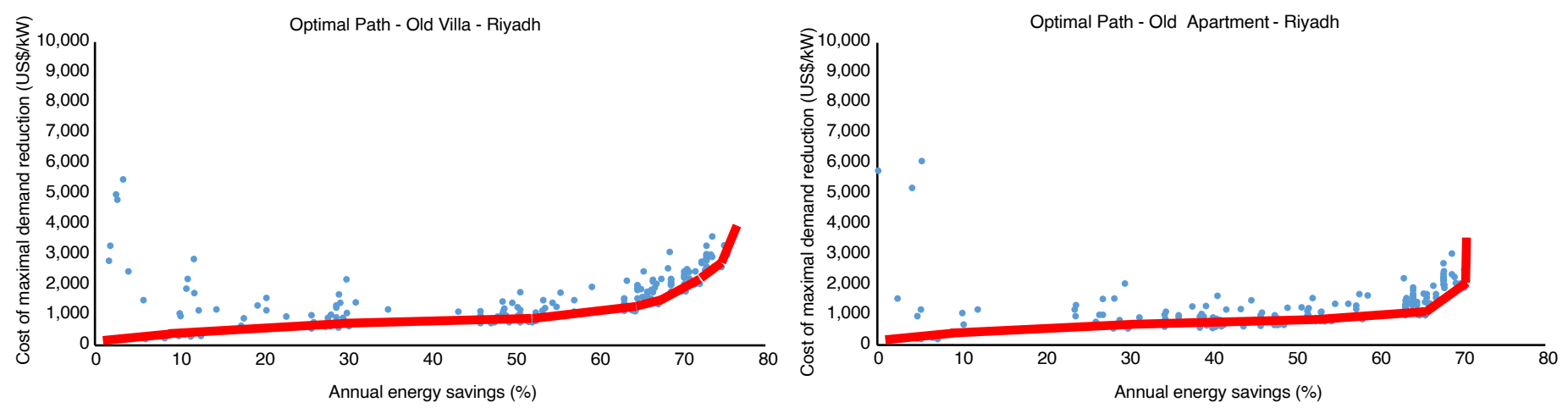

(b)
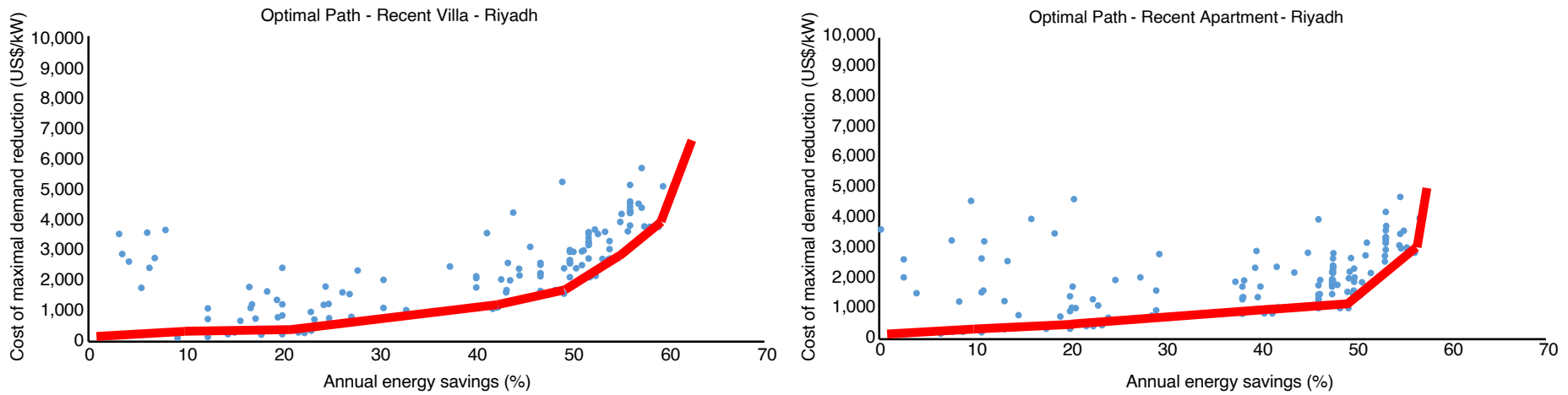

(c)
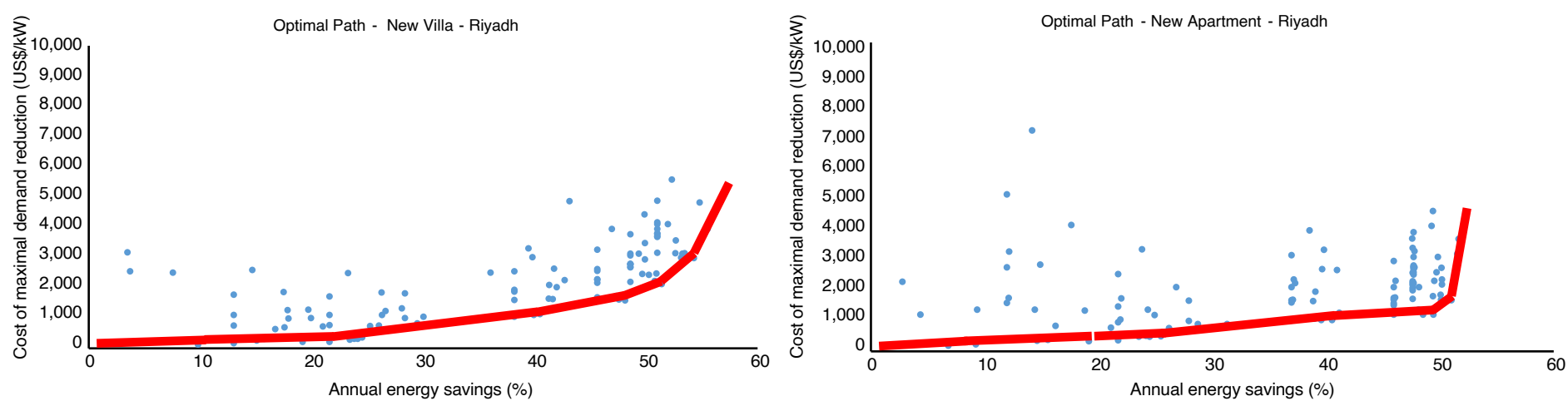

Source: Authors. 
Table 6 lists the various EE measures that are selected sequentially in each of the iterations of the optimization approach. We perform the analysis for Saudi housing units of all types, vintages and locations. Table 6 shows that the least expensive EE measures with the greatest potential to reduce energy use and demand are selected first. These measures include more energy-efficient lighting and air infiltration reduction. For old vintages, the most effective EE measure is either more efficient air conditioners or insulation for walls depending on the location. Installing double-pane windows is very expensive with little energy savings potential. Thus, it is selected as the last measure by the sequential optimization for both old and recent vintages with single-pane windows.

Table 6. List of measures selected after each iteration by the sequential optimization for all Saudi housing units.

\begin{tabular}{|c|c|c|c|c|c|c|c|c|c|c|}
\hline \multirow{6}{*}{0} & Riyadh & EER12 & Light70 & Roof_R8 & Wall_R8 & Equip65 & Infilt_70 & Overhang_05 & Cool roof & Window_DG \\
\hline & Dhahran & EER12 & Light70 & Infilt_70 & Roof_R8 & Wall_R8 & Equip65 & Overhang_05 & Cool roof & Window_DG \\
\hline & Jeddah & EER12 & Light70 & Infilt_70 & Cool_Roof & Equip65 & Roof_R8 & WallR8 & Overhang_05 & Window_DG \\
\hline & Abha & Light70 & wall_R8 & Roof_R8 & Infilt70 & Equip65 & Overhang_05 & EER12 & Cool roof & Window_DG \\
\hline & Tabuk & Wall_R8 & roof_R8 & Infilt_70 & Light70 & Equip65 & EER12 & Overhang_05 & Cool roof & Window_DG \\
\hline & Jazan & EER12 & Light70 & Infilt_70 & Cool_Roof & Equip65 & Roof_R8 & WallR8 & Overhang_05 & Window_DG \\
\hline \multirow{6}{*}{$\mathrm{R}$} & Riyadh & Light70 & Infilt_70 & EER12 & Eq65 & Overhang_05 & Cool roof & Window_DG & & \\
\hline & Dhahran & Light70 & Infilt_70 & EER12 & Eq65 & Cool roof & Overhang_05 & Window_DG & & \\
\hline & Jeddah & Light70 & Infilt_70 & EER12 & Eq65 & Overhang_05 & Cool roof & Window_DG & & \\
\hline & Abha & Light70 & Infilt50 & Eq65 & EER_12 & Overhang_05 & Cool roof & Window_DG & & \\
\hline & Tabuk & Inflt70 & Light70 & EER12 & Eq65 & Overhang_05 & Cool roof & Window_DG & & \\
\hline & Jazan & Inflt70 & Light70 & EER12 & Eq65 & Overhang_05 & Cool roof & Window_DG & & \\
\hline \multirow{6}{*}{$\mathrm{N}$} & Riyadh & Light70 & Infilt_70 & EER12 & Eq65 & Overhang_05 & Cool roof & & & \\
\hline & Dhahran & Light70 & Infilt_70 & EER12 & Eq65 & Overhang_05 & Cool roof & & & \\
\hline & Jeddah & Light70 & Infilt_70 & EER12 & Eq65 & Overhang_05 & Cool roof & & & \\
\hline & Abha & Light70 & Infilt_70 & EER12 & Eq65 & Overhang_05 & Cool roof & & & \\
\hline & Tabuk & Inflt70 & Light70 & EER12 & Eq65 & Overhang_05 & Cool roof & & & \\
\hline & Jazan & Light70 & Infilt_70 & EER12 & Eq65 & Overhang_05 & Cool roof & & & \\
\hline
\end{tabular}




\begin{tabular}{|c|c|c|c|c|c|c|c|c|c|c|}
\hline \multirow{6}{*}{$\mathrm{O}$} & Riyadh & Infilt70 & roof_R8 & WallR8 & Light70 & EER12 & Cool roof & Equip65 & Overhang_05 & Window_DG \\
\hline & Dhahran & Light70 & Infilt70 & EER12 & Roof_R8 & Wall_R8 & Cool roof & Equip65 & Overhang_05 & Window_DG \\
\hline & Jeddah & Light70 & Infilt70 & EER12 & Roof_R8 & Wall_R8 & Cool roof & Equip65 & Overhang_05 & Window_DG \\
\hline & Abha & Light70 & Infilt70 & WallR8 & Roof_R8 & Eq65 & Cool roof & EER12 & Overhang_05 & Window_DG \\
\hline & Tabuk & Light70 & Infilt70 & EER12 & Roof_R8 & Wall_R8 & Cool roof & Equip65 & Overhang_05 & Window_DG \\
\hline & Jazan & Infilt70 & Light70 & EER12 & Roof_R8 & Wall_R8 & Cool roof & Equip65 & Overhang_05 & Window_DG \\
\hline \multirow{6}{*}{$\mathrm{R}$} & Riyadh & Infilt70 & Light70 & EER12 & Eq65 & Overhang_05 & Cool roof & Window_DG & & \\
\hline & Dhahran & Light70 & Infilt70 & EER12 & Eq65 & Overhang_05 & Cool roof & Window_DG & & \\
\hline & Jeddah & Light70 & Infilt70 & EER12 & Eq65 & Overhang_05 & Cool roof & Window_DG & & \\
\hline & Abha & Light70 & Infilt50 & Eq65 & EER_12 & Overhang_05 & Cool roof & Window_DG & & \\
\hline & Tabuk & Light70 & Infilt70 & EER12 & Eq65 & Overhang_05 & Cool roof & Window_DG & & \\
\hline & Jazan & Infilt70 & Light70 & EER12 & Eq65 & Overhang_05 & Cool roof & Window_DG & & \\
\hline \multirow{6}{*}{$\mathrm{N}$} & Riyadh & Infilt70 & Light70 & EER12 & Eq65 & Overhang_05 & Cool roof & & & \\
\hline & Dhahran & Light70 & Infilt70 & Eq65 & EER_12 & Overhang_05 & Cool roof & & & \\
\hline & Jeddah & Light70 & Infilt70 & Eq65 & EER_12 & Overhang_05 & Cool roof & & & \\
\hline & Abha & Light70 & Infilt50 & Eq65 & EER_12 & Overhang_05 & Cool roof & & & \\
\hline & Tabuk & Light70 & Infilt70 & EER12 & Eq65 & Overhang_05 & Cool roof & & & \\
\hline & Jazan & Light70 & Infilt70 & Eq65 & EER_12 & Overhang_05 & Cool roof & & & \\
\hline
\end{tabular}




\begin{tabular}{|c|c|c|c|c|c|c|c|c|c|c|}
\hline \multirow{6}{*}{0} & Riyadh & Wall_R8 & roof_R8 & Infilt_70 & Light70 & Equip65 & EER12 & coolroof & Overhang_05 & Window_DG \\
\hline & Dhahran & EER12 & Light70 & Infilt_70 & Eq65 & Wall_R8 & Roof_R8 & coolroof & Overhang_05 & Window_DG \\
\hline & Jeddah & EER12 & Light70 & Infilt_70 & Eq65 & Wall_R8 & Roof_R8 & coolroof & Overhang_05 & Window_DG \\
\hline & Abha & Light70 & wall_R8 & Roof_R8 & Infilt70 & Equip65 & EER12 & Overhang_05 & Cool roof & Window_DG \\
\hline & Tabuk & Wall_R8 & Infilt70 & Roof_R8 & Light70 & EER12 & Equip30 & Overhang_05 & Cool roof & Window_DG \\
\hline & Jazan & EER12 & Light70 & Infilt_70 & Eq65 & Wall_R8 & Roof_R8 & coolroof & Overhang_05 & Window_DG \\
\hline \multirow{6}{*}{$\mathrm{R}$} & Riyadh & Light70 & Infilt70 & EER12 & Eq65 & Cool roof & Overhang_05 & Window_DG & & \\
\hline & Dhahran & Light70 & Infilt70 & EER12 & Cool_Roof & Equip30 & Overhang_05 & Window_DG & & \\
\hline & Jeddah & Light70 & Infilt70 & EER12 & Eq65 & Cool roof & Overhang_05 & Window_DG & & \\
\hline & Abha & Light70 & Infilt70 & Eq65 & Cool_Roof & EER12 & Overhang_05 & Window_DG & & \\
\hline & Tabuk & Inflt70 & Light70 & EER12 & Eq65 & Cool roof & Overhang_05 & Window_DG & & \\
\hline & Jazan & Inflt70 & Light70 & EER12 & Eq65 & Cool roof & Overhang_05 & Window_DG & & \\
\hline \multirow{6}{*}{$N$} & Riyadh & Light70 & Infilt70 & EER12 & Eq65 & Cool roof & Overhang_05 & & & \\
\hline & Dhahran & Light70 & Infilt70 & EER12 & Eq65 & Cool roof & Overhang_05 & & & \\
\hline & Jeddah & Light70 & Infilt70 & EER12 & Eq65 & Cool roof & Overhang_05 & & & \\
\hline & Abha & Light70 & Infilt70 & Eq65 & EER_12 & Cool roof & Overhang_05 & & & \\
\hline & Tabuk & Inflt70 & Light70 & EER12 & Eq65 & Cool roof & Overhang_05 & & & \\
\hline & Jazan & Light70 & Infilt70 & EER12 & Eq65 & Cool roof & Overhang_05 & & & \\
\hline
\end{tabular}

Impact of energy retrofit programs on the overall housing stock

In this subsection, we consider three retrofit scenarios for each housing type, vintage and location using the optimization results in Table 6. Specifically, these three retrofit cases depend on the number of EE measures and, thus, the capital costs to implement the retrofit programs. 
EEM-1 is the retrofit program in which just one EE measure is implemented for each housing unit. This measure is the first action identified by the optimization analysis, as shown in Table 6.

EEM-3 is the retrofit program in which the first three EE measures listed in Table 6 are implemented for each housing unit type, vintage and location.
EEM-5 is the retrofit scenario in which five EE measures are implemented for each housing type. The measures are applied in the order indicated in Table 6. This retrofit program requires the highest capital costs to deploy.

Table 7 lists the capital costs required for each retrofit program for the existing housing stock by type and vintage. As expected, when more EE measures are deployed for each housing unit, the capital costs for the retrofit programs are higher. Specifically, the capital costs increase from $\$ 4.92$ billion for one EE measure to $\$ 30.39$ billion for five EE measures. For all housing types and retrofit programs, the capital costs are greater for the old vintages.

Table 7. Capital costs (expressed in $\$$ billion) required for various retrofit programs.

\begin{tabular}{|c|c|c|c|c|c|c|c|c|c|c|}
\hline \multirow{2}{*}{$\begin{array}{c}\text { Type } \\
\text { Vintage }\end{array}$} & \multicolumn{3}{|c|}{ TH } & \multicolumn{3}{|c|}{ VL } & \multicolumn{3}{|c|}{ AP } & \multirow{2}{*}{$\begin{array}{l}\text { Housing } \\
\text { stock }\end{array}$} \\
\hline & 0 & $\mathrm{R}$ & $\mathrm{N}$ & o & $\mathrm{R}$ & $N$ & 0 & $\mathrm{R}$ & $\mathrm{N}$ & \\
\hline EEM-1 & 2.31 & 0.04 & 0.01 & 0.52 & 0.14 & 0.04 & 1.73 & 0.10 & 0.03 & 4.92 \\
\hline EEM-3 & 3.65 & 0.34 & 0.11 & 5.97 & 1.29 & 0.37 & 3.14 & 0.75 & 0.24 & 15.85 \\
\hline EEM-5 & 6.85 & 0.72 & 0.23 & 10.94 & 2.65 & 0.83 & 6.06 & 1.59 & 0.53 & 30.39 \\
\hline
\end{tabular}

Source: Authors.

Note: $\mathrm{TH}=$ traditional house; $\mathrm{VL}=$ villa; $\mathrm{AP}=$ apartment.

Figure 14 shows the impacts of the three retrofit programs on the hourly electricity load for the Saudi housing stock. We consider a winter week (Figure 14[a]) and a summer week (Figure 14[b]). As Figure 14 clearly indicates, the electrical load decreases as the number of EE retrofitting measures increases during both winter and summer. Specifically, Figure 14(a) shows that the electricity profiles are irregular during the winter in all scenarios. Several peaks are associated with the use of electrical heating, especially at night, in some regions. In other regions, peaks are associated with cooling during daytime hours. In contrast, the daily load profiles during the summer, shown in Figure 14(b), are more regular. Clear daily peaks occur when the demand for air conditioning is high during early afternoon hours. 
Figure 15 compares the hourly electrical profiles for the Saudi housing stock during the entire year. We show time series (Figure 15[a]) and load duration curves (Figure 15[b]) for the three retrofitting programs relative to the baseline scenario. As expected, these programs significantly reduce both peak demand and the annual energy consumption of Saudi Arabia's housing stock.

Figure 14. Hourly variation in the electrical load of the Saudi housing stock during (a) a winter week (January 15 to 22) and (b) a summer week (July 15 to 22).

(a)

Winter week load profile

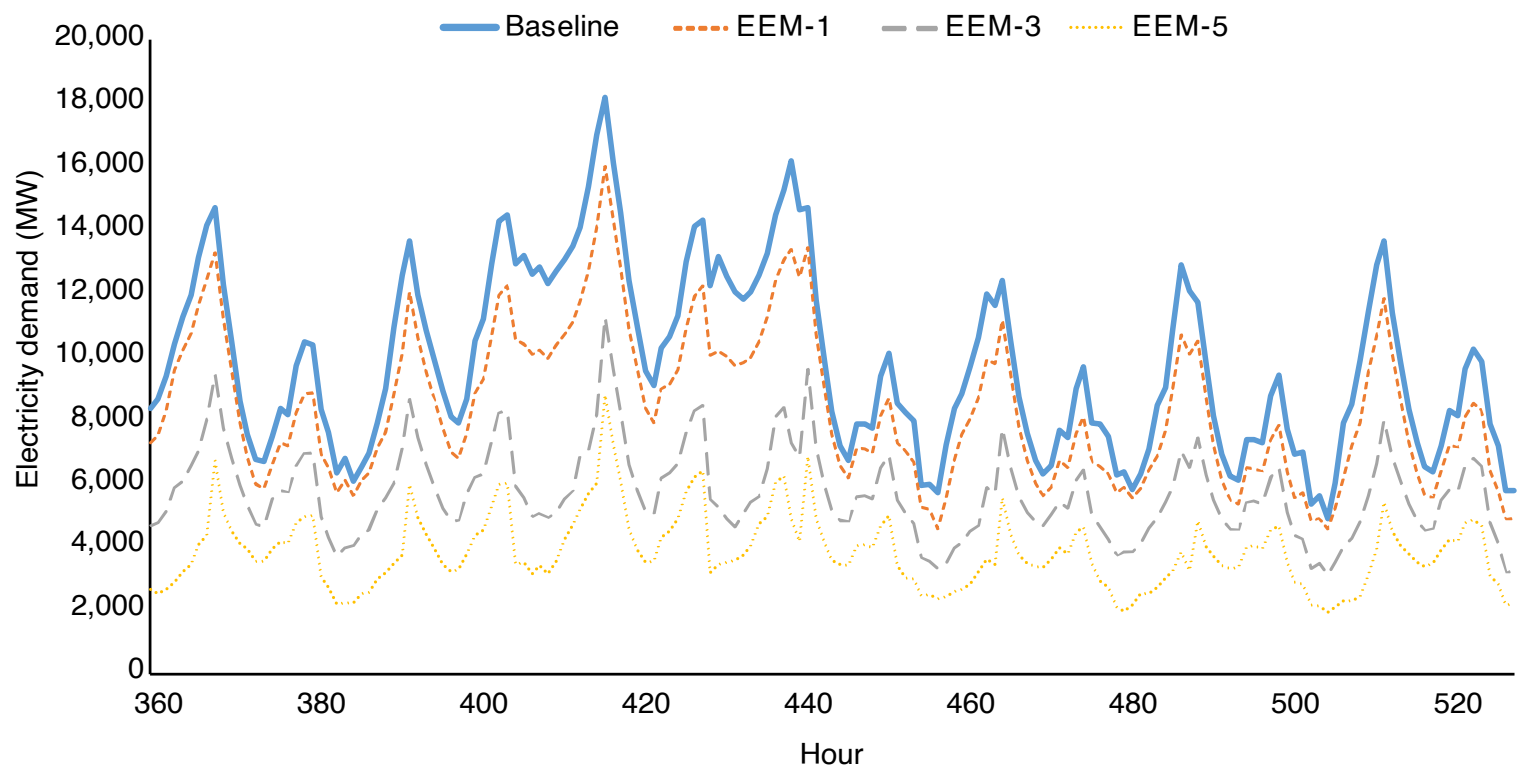

(b)

Summer week load profile

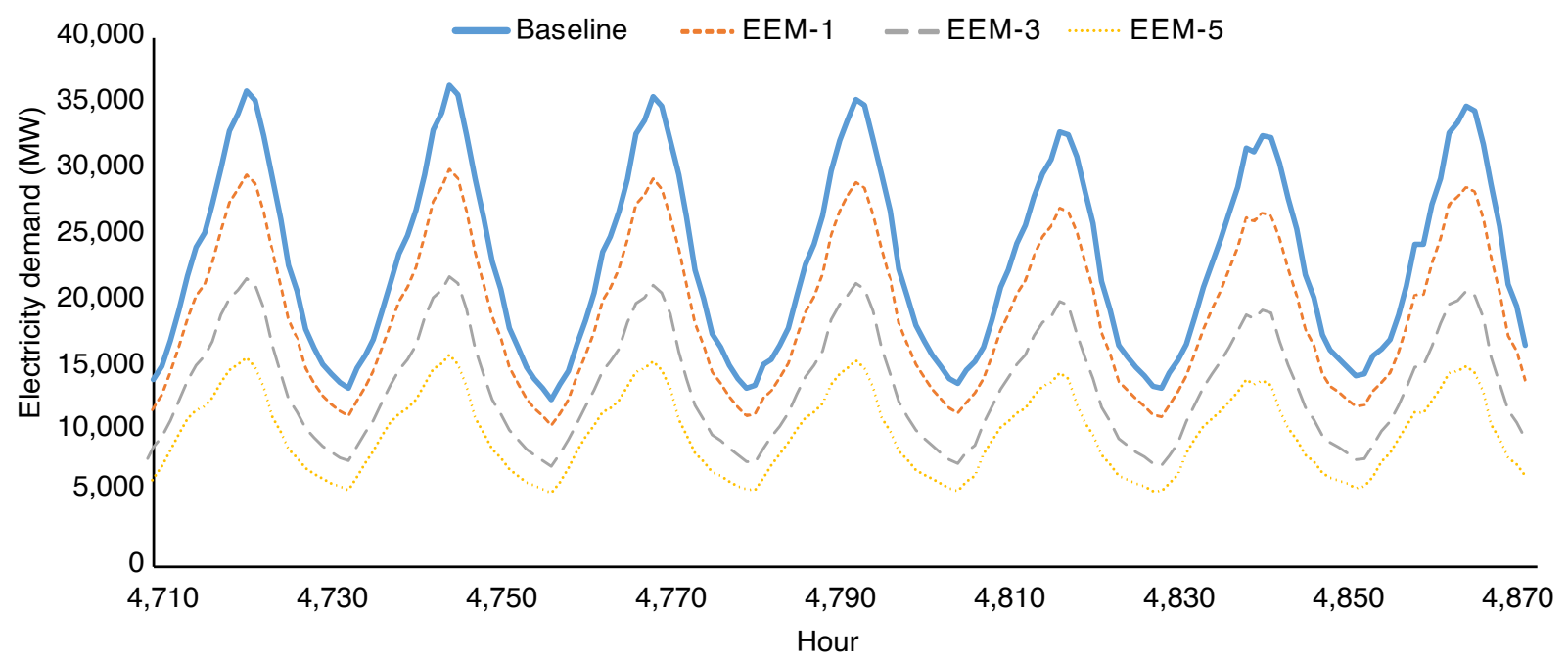


Figure 15. Hourly variation in the electrical loads of the Saudi housing stock for three retrofit cases compared with the baseline using (a) time series and (b) load duration curves.

(a)

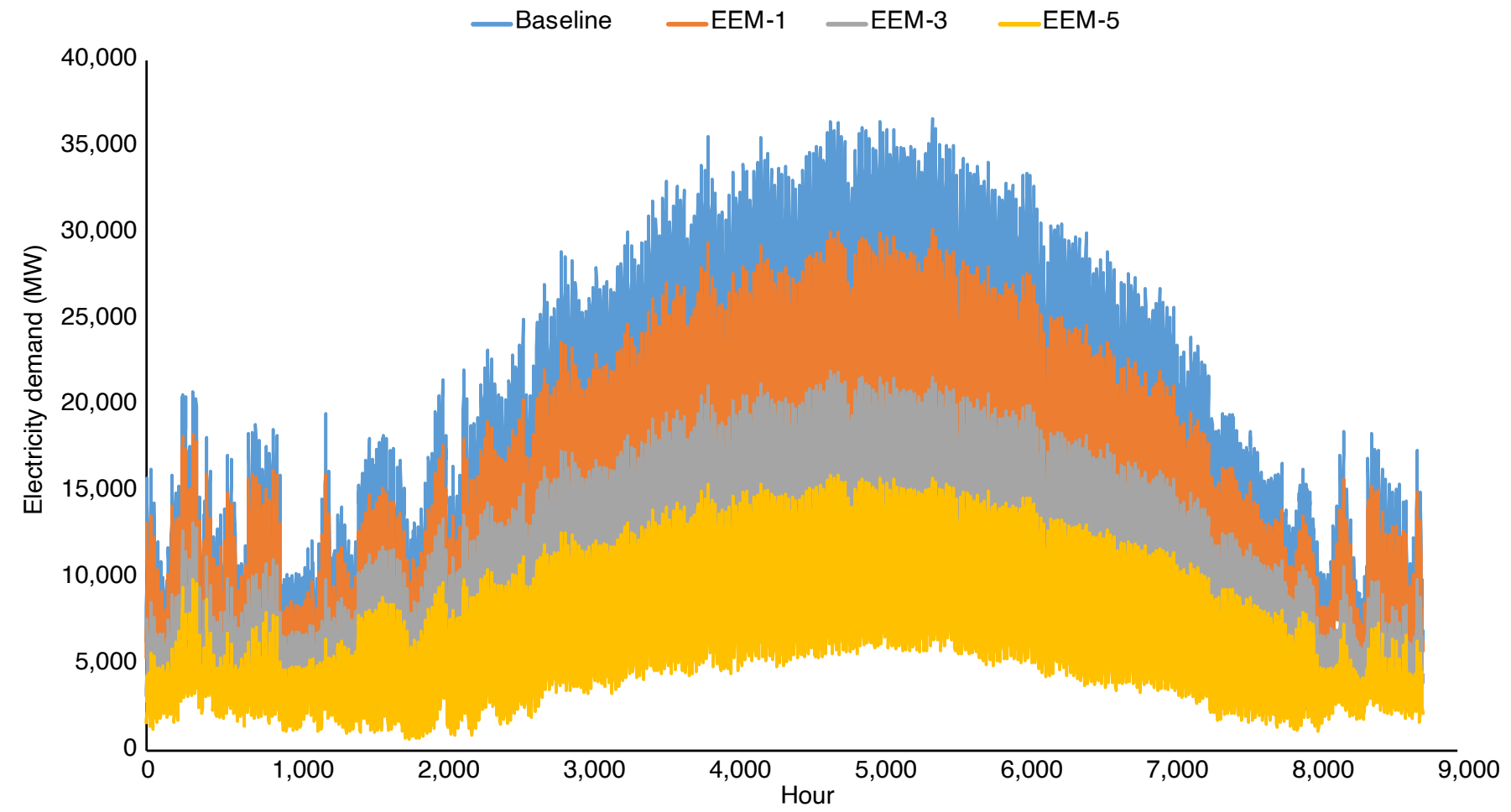

(b)

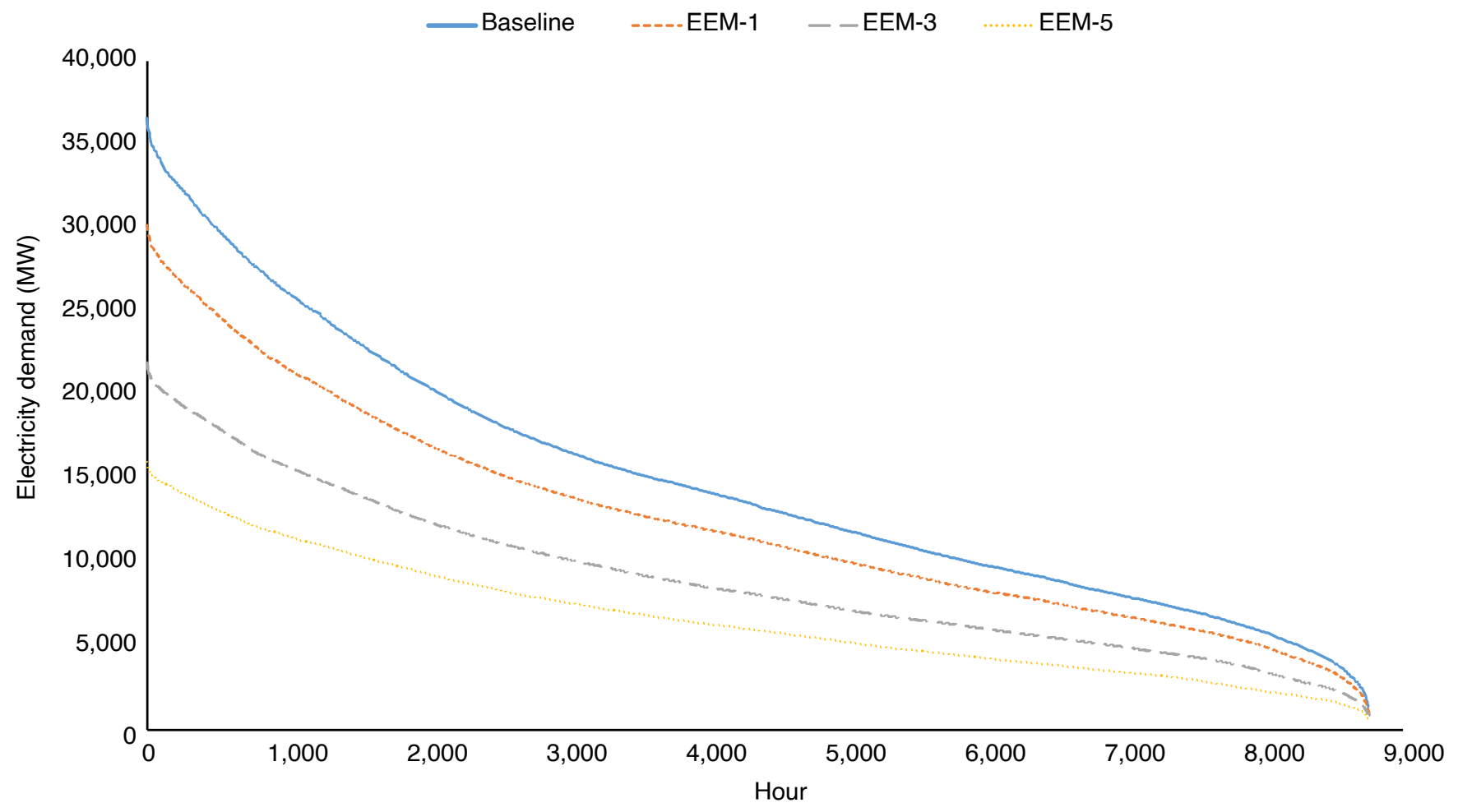

Source: Authors. 
Table 8 summarizes the main characteristics of the electrical load profiles for the baseline and the three retrofit programs. We assume that these programs are deployed for the entire Saudi housing stock. As expected, peak demand and average annual consumption fall as the retrofitting becomes more aggressive. For instance, the reduction in peak demand is $17.5 \%$ for the retrofit program with one EE measure. The retrofit program with five EE measures reduces peak demand by $56.3 \%$. All of the retrofit programs achieve reductions in annual electricity consumption of similar orders of magnitude, as indicated by the unchanged load factors. The gaps between the peak and base demands narrow owing to the implementation of more aggressive retrofit programs. Thus, the load curve flattens, which is a desirable outcome for the electrical grid system. Moreover, Table 8 indicates that the number of hours when the load is above $95 \%$ of peak demand falls with more aggressive retrofitting. This outcome reduces the period in which peak demand generation plants are used.

Table 8. Main characteristics of the electricity load profiles for the baseline and three retrofitting programs.

\begin{tabular}{l|l|l|l|l} 
Metric & Baseline & EEM-1 & EEM-3 & EEM-5 \\
\hline Peak demand (MW) & 36,628 & 30,320 & 21,997 & 16,002 \\
\hline Average load (MW) & 14,910 & 12,482 & 9,045 & 6,613 \\
\hline Load factor & 0.41 & 0.41 & 0.41 & 0.41 \\
\hline Ratio of peak demand to baseload & 29.3 & 28.3 & 24.6 & 24.7 \\
\hline $\begin{array}{l}\text { Number of hours with a load above } \\
\text { 95\% of the peak }\end{array}$ & 50 & 48 & 48 & 37 \\
\hline $\begin{array}{l}\text { Number of hours with a load above } \\
90 \% \text { of the peak }\end{array}$ & 183 & 190 & 191 & 197
\end{tabular}

Impact of rooftop PV installations on the overall housing stock

Table 9 shows estimates of the rooftop PV capacities that can potentially be installed. These estimates are based on the available roof areas for various building types and vintages specific to the existing Saudi housing stock. The total PV capacity potentially available for deployment on the rooftops of Saudi houses is estimated to be $20.9 \mathrm{GW}$. Almost $50 \%$ of this capacity is located on top of villas.

Based on an installation cost of $\$ 3,000$ per $\mathrm{kW}$, the total capital costs for the PV systems are estimated to be $\$ 62.75$ billion. This cost is more than double the cost of retrofitting all of the Saudi housing stock using five EE measures (i.e., the 5-EEM program). 
Table 9. Rooftop PV capacities (expressed in MW) for various Saudi building types, vintages and regions.

\begin{tabular}{|c|c|c|c|c|c|c|c|c|c|c|}
\hline \multirow{2}{*}{ Region } & \multicolumn{3}{|c|}{ TH } & \multicolumn{3}{|c|}{ VL } & \multicolumn{3}{|c|}{ AP } & \multirow{2}{*}{ Total } \\
\hline & o & $\mathrm{R}$ & $\mathrm{N}$ & 0 & $\mathrm{R}$ & $\mathrm{N}$ & 0 & $\mathrm{R}$ & $\mathrm{N}$ & \\
\hline Middle & 966 & 56 & 18 & 4,219 & 991 & 308 & 971 & 415 & 127 & 8,068 \\
\hline East & 343 & 17 & 6 & 1,277 & 298 & 89 & 836 & 254 & 77 & 3,197 \\
\hline West & 1,941 & 227 & 66 & 1,111 & 463 & 136 & 2,009 & 484 & 153 & 6,588 \\
\hline South & 568 & 124 & 44 & 972 & 413 & 150 & 489 & 223 & 81 & 3,064 \\
\hline Total & 3,817 & 424 & 133 & 7,578 & 2,165 & 682 & 4,305 & 1,375 & 438 & 20,917 \\
\hline
\end{tabular}

Source: Authors.

The recently approved net-metering program for deploying small PV systems has a limited capacity of $1.8 \mathrm{GW}$ nationwide (WERA 2020b). This amount is roughly $10 \%$ of the potential rooftop PV capacity available from the existing housing stock. The plan is to increase the cap on small PV installations after the initiative's initial rollout. Figure 16 illustrates the hourly electricity loads for the Saudi housing stock during a winter week (Figure 16[a]) and a summer week (Figure 16[b]). We consider the baseline and rooftop PV penetration levels of $100 \%, 50 \%$ and $10 \%$ of the total available roof area. As expected, the impact of rooftop PV systems on the electrical load profile is more evident as the penetration level increases. For both winter and summer days, the rooftop PV systems generate electricity and reduce the housing stock's load only around midday (i.e.,
10 a.m. to 3 p.m.). These periods coincide mostly with low energy demand hours during the winter, as illustrated in Figure 16(a). In the summer, the power generated by the rooftop PV systems does reduce energy use around midday. However, it does not significantly lower peak demand, which occurs mostly during the late afternoon, as Figure 16(b) shows.

Figure 17 shows the impacts of the rooftop PV systems on the entire housing stock's hourly electrical load profile for the three PV penetration levels. The load duration curves in Figure 17 clearly show that even with $100 \%$ penetration, the PV systems do not reduce peak demand significantly. The retrofitting programs discussed in Section 4.3 are more effective. 
Figure 16. Hourly variation in the electrical load of the Saudi housing stock for three PV penetration levels during (a) a winter week (January 15 to 22) and (b) a summer week (July 15 to 22).

(a)

Winter week load profile

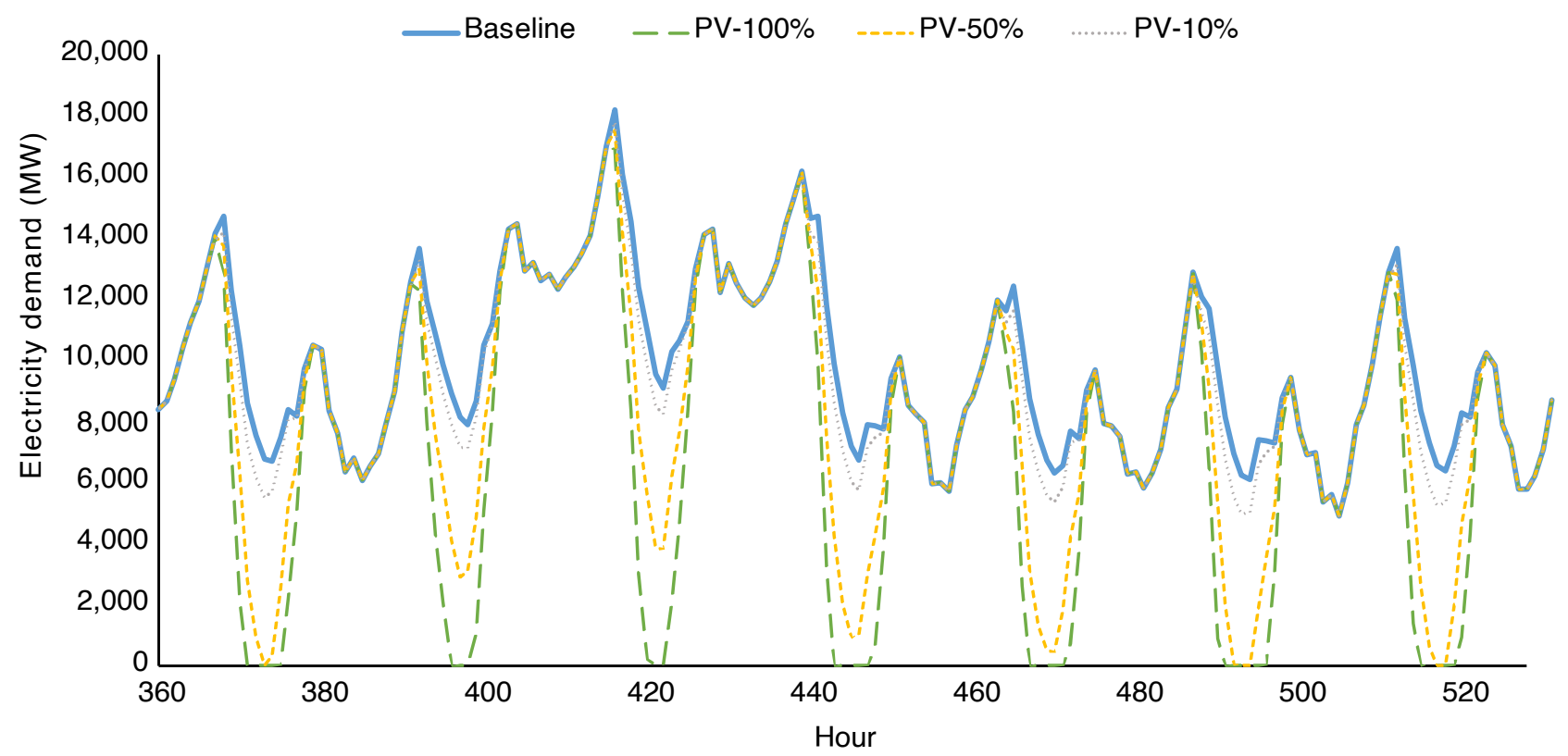

(b)

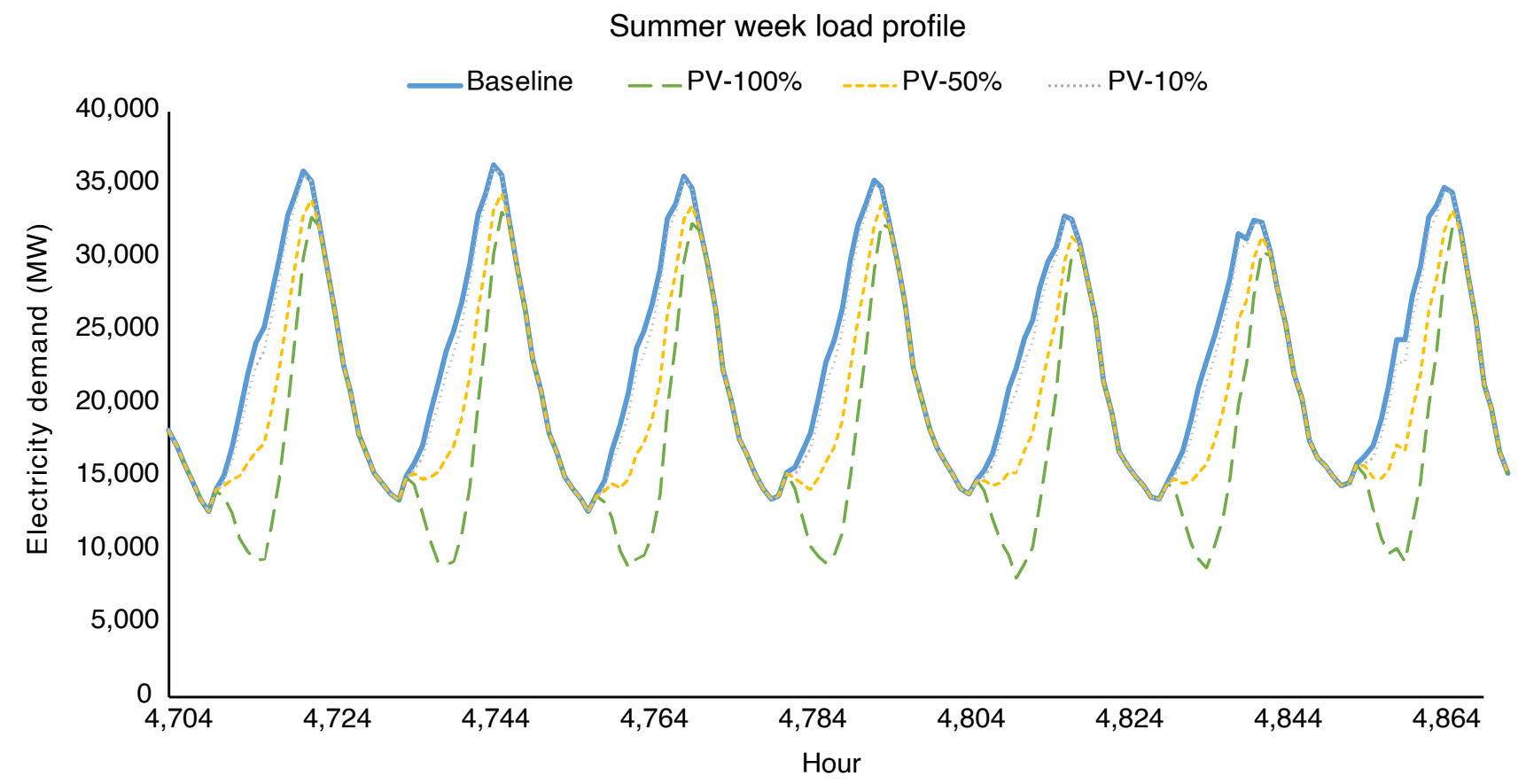

Source: Authors. 
Figure 17. Electrical load duration curve for the Saudi housing stock in the baseline case and three rooftop PV penetration scenarios.

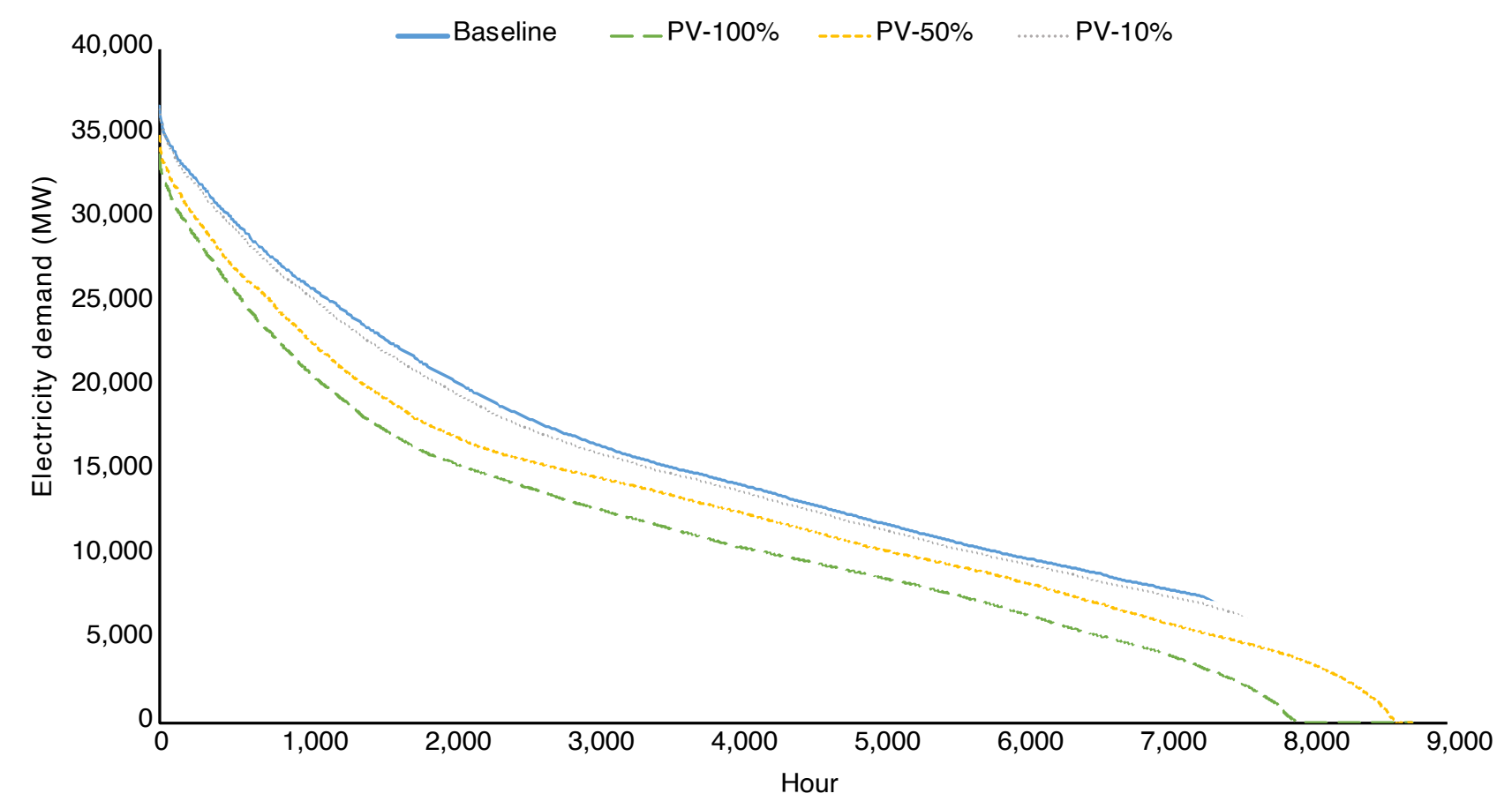

Source: Authors. 


\section{Cost-Benefit Analysis}

$\mathrm{T}$ The results in Section 4 show that the retrofit programs generally have more significant impacts than the rooftop PV programs have for all penetration levels. This result holds for both energy use and peak demand reductions. This section analyzes the cost effectiveness of the EE and PV programs to determine their economic benefits given the capital costs required for their deployment. This analysis assumes that the production cost of electricity in Saudi Arabia is $\$ 0.10$ per kWh (Krarti, Aldubyan, and Williams 2020; Krarti, Dubey, and Howarth 2017). Figure 18 summarizes the energy and economic indicators for the six programs considered in this study, as follows.

Percent peak demand savings versus annual energy use savings (Figure 18[a]): The peak demand and annual energy use savings from the retrofit programs range from $17.2 \%$ (EEM-1) to $56.3 \%$ (EEM-5). The peak demand savings associated with rooftop PV systems range from only $0.6 \%$ (PV-10\%) to $7.5 \%$ (PV-100\%).

Payback period versus annual energy use savings (Figure 18[b]): The retrofit programs have payback periods ranging from 2.3 years (EEM-1) to 4.2 years (EEM-5). In contrast, the rooftop PV systems take significantly longer to recover their installation costs. Their payback periods range from 16.3 years (PV-10\%) to 17.7 years (PV-100\%).

The cost of saved peak demand versus the cost of saved annual energy use (Figure 18[c]): The estimated cost to reduce annual energy use by one unit ranges from $\$ 0.23$ per $\mathrm{kWh}$ (EEM-1) to $\$ 0.43$ per kWh (EEM-3) for the retrofit programs. However, it jumps to $\$ 16.3$ per kWh (PV-10\%) and $\$ 17.7$ per kWh (PV-100\%) for the rooftop PV systems.
The cost of saved peak demand versus annual energy use savings (Figure 18[d]): The cost of saved peak demand ranges from $\$ 780$ per kW (EEM-1) to $\$ 1,473$ per kW (EEM-5) for the retrofit programs. These costs are significantly lower than that the estimates for the rooftop PV systems, which are \$29,186 per kW (PV-10\%) and $\$ 22,711$ per $\mathrm{kW}(\mathrm{PV}-100 \%)$.

The payback periods for both programs are longer if we consider the electricity price paid by households, which is lower than the production cost. However, this difference is smaller after the recent price reforms (WERA 2020a; SEC 2020). Furthermore, additional cost benefits can be achieved for all evaluated programs from the Saudi government's perspective if other benefits are accounted for. These benefits include less need to construct future power plants and carbon emission reductions (Krarti, Dubey, and Howarth 2017).

The results in Figure 18 confirm that large-scale retrofit programs are highly effective relative to rooftop PV installations. These programs can more effectively reduce both the peak demand and the annual energy consumption of the existing Saudi housing stock. The retrofit programs offer lower capital costs compared with the PV systems. Additionally, they can provide electricity demand reductions when they are needed most, that is, during periods when the consumption is highest.

Figure 19 illustrates this property for a typical summer day. It shows the hourly electricity saved by the three retrofit programs and the hourly electricity generated by the three PV systems on July 15 . The retrofit programs save the most energy during the late afternoon hours (i.e., 4 p.m. to 6 p.m.). At this time, the housing stock's air conditioning load is at its highest. Effectively, the retrofit programs act as generators that provide power throughout the day, with peak output coinciding with the housing stock's 
peak demand. In contrast, the PV systems produce power only during the day. Their highest output is too early in the day (i.e., around 1 p.m.) to offer any significant assistance in reducing peak demand.

Figure 18. Comparative analysis of the impacts of retrofit programs and PV penetration on energy consumption, peak demand and cost benefits for the Saudi housing stock.

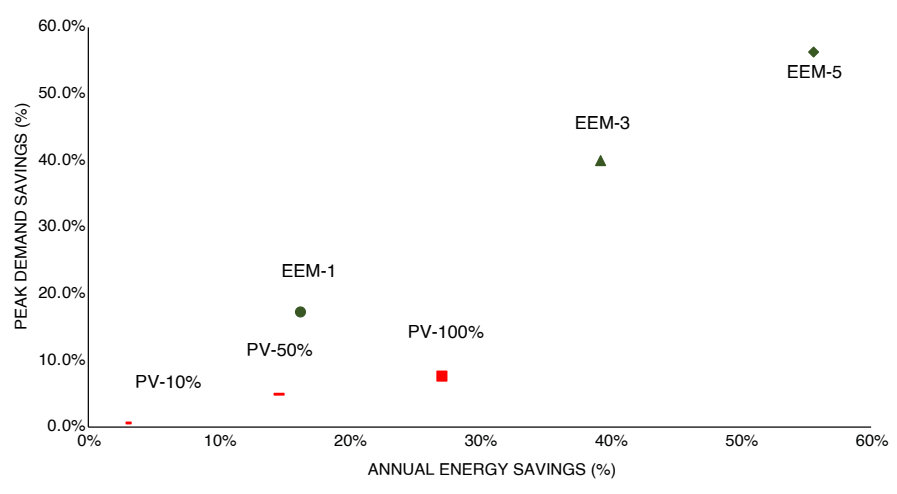

(a)

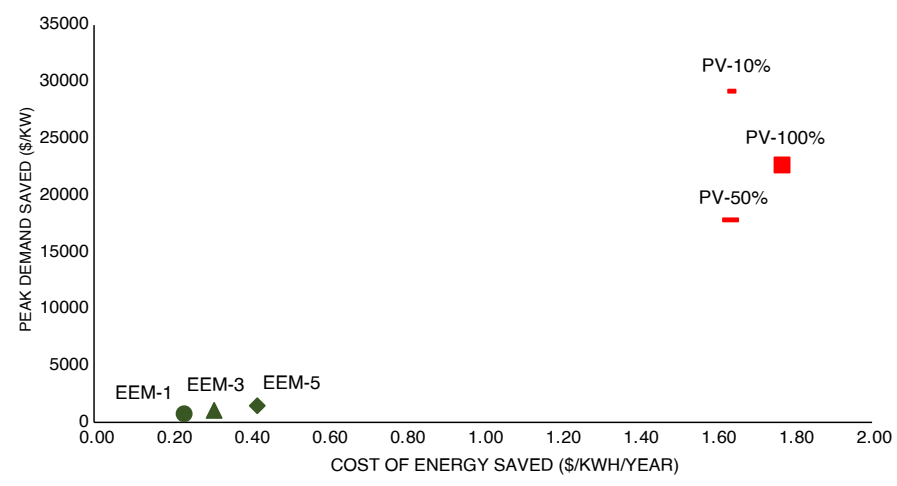

(c)

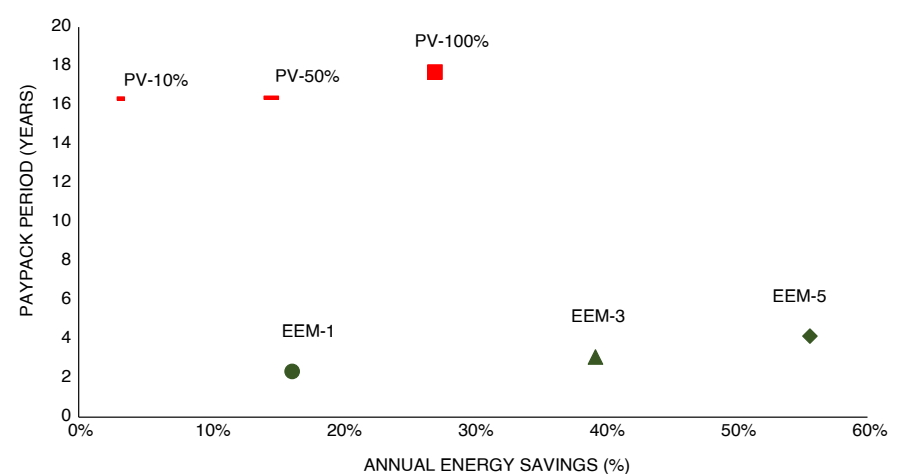

(b)

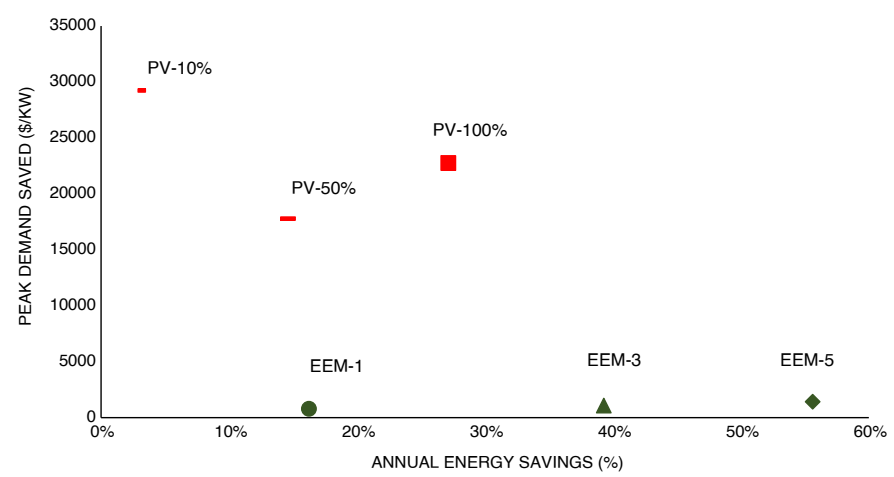

(d)

Source: Authors.

Figure 20 compares the annual hourly profiles of energy saved and generated by the retrofit programs and the PV systems. It is clear that the PV systems do not generate any electricity for almost half of the year. In contrast, the retrofit programs are able to reduce electricity demand during all hours of the year, including the important peak demand hours. 
Figure 19. Comparative hourly profiles of the energy saved by retrofit programs and the electricity generated by PV systems for the Saudi housing stock on July 15.

\section{Summer week load profile}

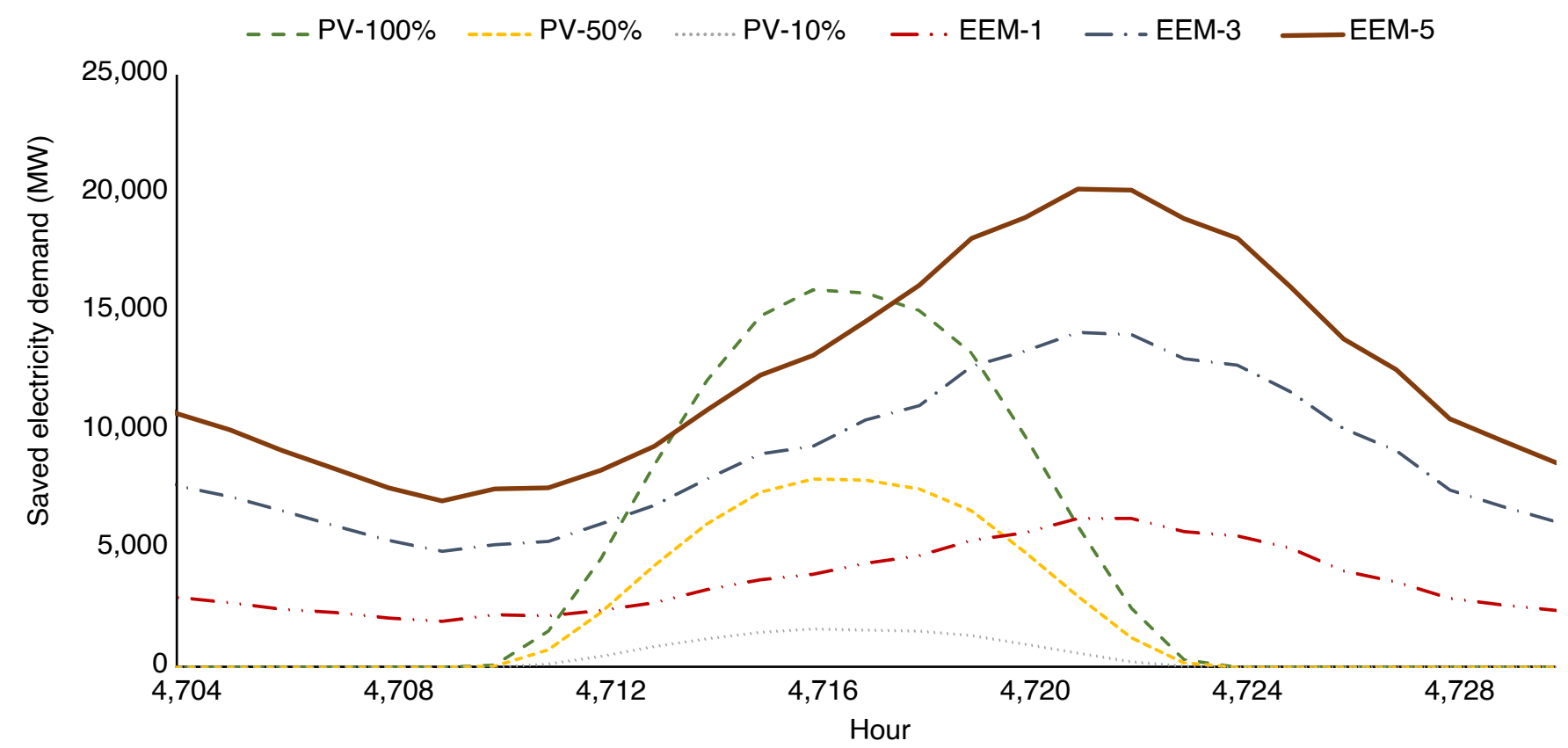

Source: Authors.

Figure 20. Comparative hourly profiles of the energy saved by retrofit programs and the electricity generated by PV systems for the Saudi housing stock over one year.

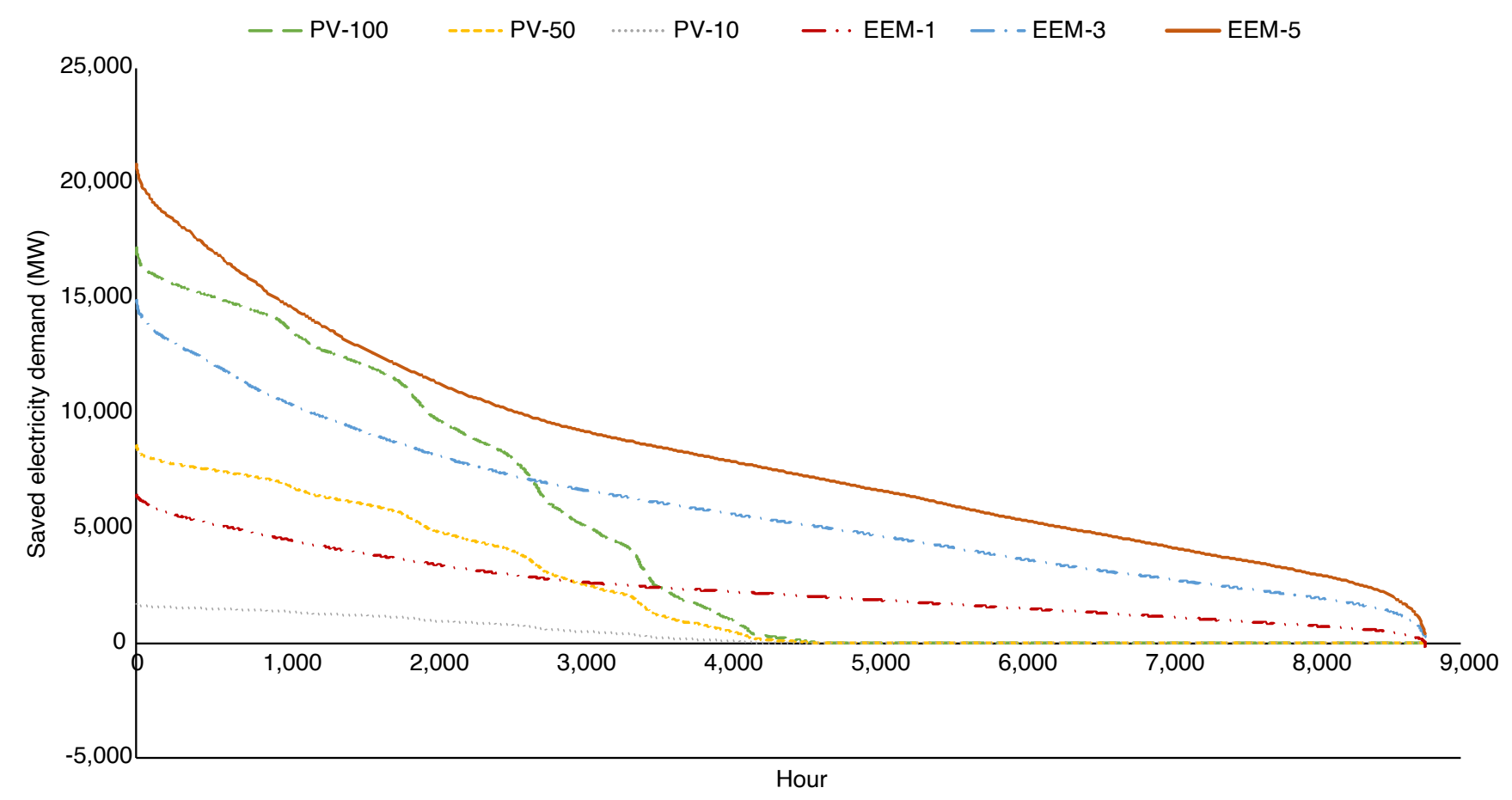

Source: Authors. 


\section{Summary and Conclusions}

his paper proposes a new optimization approach using the sequential search technique to identify the most effective EE measures for residential buildings. The selected measures should reduce peak electricity demand and decrease annual energy consumption as cost-effectively as possible. We applied this approach to determine the optimal sets of $E E$ measures for large-scale retrofitting programs specific to Saudi Arabia's residential building stock. In particular, we carried out the optimization analysis for 56 housing prototypes representing the existing building stock. We considered various types, vintages and locations within Saudi Arabia.

The results indicate that $E E$ retrofit programs are the most effective way to reduce peak demand. This result holds for any desired level of annual energy consumption and for all types of housing units considered for Saudi Arabia. The optimization approach shows that the cost of reducing peak demand is lower for old vintages than for new vintages. This result holds for any housing type and energy use savings target. For instance, a $40 \%$ reduction in annual energy consumption for an old traditional house requires $\$ 1,000$ per $\mathrm{kW}$ of peak demand reduction. Investments of $\$ 2,000$ per $\mathrm{kW}$ are needed to achieve the same EE level for the new traditional house prototype.
We also compared large-scale EE and rooftop PV deployments. The optimization shows that retrofit programs are highly cost-effective and significantly better than PV systems for reducing peak demand among the Saudi housing stock. Specifically, the analysis finds that retrofitting the housing stock with just one EE measure reduces peak demand by 6.3 GW. This reduction is more than double the effect of installing PV systems on all available residential roof areas. Moreover, the EE measure costs significantly less (i.e., $\$ 4.9$ billion versus $\$ 62.75$ billion). The peak demand reduction associated with this one retrofit program costs $\$ 779$ per $\mathrm{kW}$. This cost is substantially lower than the effective estimate of $\$ 22,710$ per $\mathrm{kW}$ for $100 \%$ rooftop PV systems.

The optimization approach presented in this paper is an effective way to identify and design targeted large-scale programs. Utilities and governments can deploy these programs to not only reduce existing buildings' energy consumption but also cost-effectively lower their peak electricity demand. 


\section{References}

Alaidroos, Alaa, and Moncef Krarti. 2015. "Optimal Design of Residential Building Envelope Systems in the Kingdom of Saudi Arabia." Energy and Buildings 86:104-17. DOI: 10.1016/j.enbuild.2014.09.083

Alasseri, Rajeev, Ashish Tripathi, T. Joji Rao, and K. J. Sreekanth. 2017. "A Review on Implementation Strategies for Demand Side Management (DSM) in Kuwait Through Incentive-based Demand Response Programs." Renewable Sustainable Energy Reviews 77:617-35. DOI: 10.1016/j. rser.2017.04.023

Bahl, Björn, Matthias Lampe, Philip Voll, and André Bardow. 2017. "Optimization-based Identification and Quantification of Demand-side Management Potential for Distributed Energy Supply Systems." Energy 135:889-99. DOI: 10.1016/j. energy.2017.06.083

Behboodi, Sahand, David P. Chassin, Curran Crawford, and Ned Djilali. 2016. "Renewable Resources Portfolio Optimization in the Presence of Demand Response." Applied Energy 162:139-48. DOI: 10.1016/j.apenergy.2015.10.074

Behrangrad, Mahdi. 2015. "A Review of Demand Side Management Business Models in the Electricity Market." Renewable and Sustainable Energy Reviews 47:270-83. DOI: 10.1016/j. rser.2015.03.033

Bergaentzlé, Claire, Cédric Clastres, and Haikel Khalfallay. 2014. "Demand-side Management and European Environmental and Energy Goals: An Optimal Complementary Approach." Energy Policy 67:858-69. DOI: 10.1016/j.enpol.2013.12.008

Bradley, Peter, Matthew Leach, and Jacopo Torriti. 2013. "A Review of the Costs and Benefits of Demand Response for Electricity in the UK." Energy Policy 52:312-27. DOI: 10.1016/j.enpol.2012.09.039
Christensen, Craig, Greg Barker, and Scott Horowitz. 2004. "A Sequential Search Technique for Identifying Optimal Building Designs on the Path to Zero Net Energy." Proceedings of the Solar Conference 2004, Portland, OR, American Solar Energy Society.

Eissa, Moustafa Mohammed. 2011. "Demand Side Management Program Evaluation Based on Industrial and Commercial Field Data." Energy Policy 39:5961-69. DOI: 10.1016/j. enpol.2011.06.057

Water and Electricity Regulatory Authority (WERA). 2020a. "Data and Statistics, Electricity and Cogeneration Regulatory Authority." Accessed June 16, 2020. https://ecra.gov.sa/en-us/ dataandstatistics/pages/DataAndStatistics.aspx

-- - 2020b. Small-Scale Solar PV Systems Regulations, ERD - TA - 012 (V02/19). Riyadh: WERA.

Federal Energy Regulatory Commission (FERC). 2019. "2019 Assessment of Demand Response and Advanced Metering." https://www.ferc.gov/legal/ staff-reports/2019/DR-AM-Report2019.pdf

Ferrara, Maria, Valentina Monetti, and Enrico Fabrizio. 2018. "Cost-optimal Analysis for Nearly Zero Energy Buildings Design and Optimization: A Critical Review." Energies 11(6):1478. DOI: 10.3390/ en11061478

Frick, Natalie Mims, Ian M. Hoffman, Charles A. Goldman, Greg Leventis, Sean Murphy, and Lisa C. Schwartz. 2019. Peak Demand Impacts From Electricity Efficiency Programs. Berkeley, CA: Lawrence Berkeley National Laboratory. https:// eta-publications.lbl.gov/sites/default/files/cost_of_ saving_peak_demand_20200902final.pdf 
Gelazanskas, Linas, and Kelum A. A. Gamage. 2014. "Demand Side Management in Smart Grid: A Review and Proposals for Future Direction." Sustainable Cities and Society 11:22-30. DOI: 10.1016/j.scs.2013.11.001

Gellings, Clark W. 1996. "Then and Now: The Perspective of the Man Who Coined the Term 'DSM'.' Energy Policy 24(4):285-8. DOI: 10.1016/0301-4215(95)00134-4

General Authority for Statistics (GASTAT). 2018. "Housing Survey Data, General Authority for Statistics, Riyadh, Kingdom of Saudi Arabia." Accessed December 25, 2018. http://www.stats.gov. sa

Griego, Danielle, Moncef Krarti, and Abel Hernandez-Guerrero. 2015. "Energy Efficiency Optimization of New and Existing Office Buildings in Guanajuato, Mexico." Sustainable Cities and Society 17:132-40. DOI: 10.1016/j.scs.2015.04.008

Harish, V. S. K. V., and Arun Kumar. 2014. "Demand Side Management in India: Action Plan, Policies and Regulations." Renewable and Sustainable Energy Reviews 33:613-24. DOI: 10.1016/j.rser.2014.02.021

Ihm, Pyeongchan, and Moncef Krarti. 2012.

"Design Optimization of Energy Efficient Residential Buildings in Tunisia." Building and Environment 58(12):81-90. DOI: 10.1016/j.buildenv.2012.06.012

Ikpe, Eka, and Jacopo Torriti. 2018. "A Means to an Industrialisation End? Demand Side Management in Nigeria." Energy Policy 115:207-15. DOI: 10.1016/j. enpol.2018.01.011

International Energy Agency (IEA). 2019. "Multiple Benefits of Energy Efficiency."
Khan, Imran. 2019. "Energy-saving Behaviour as a Demand-side Management Strategy in the Developing World: The Case of Bangladesh." International Journal for Energy and Environmental Engineering 10:493-510. DOI: 10.1007/ s40095-019-0302-3

Krarti, Moncef. 2012. Weatherization of Residential Buildings. New York: Taylor and Francis Publishing.

- - - 2015. "Evaluation of Large Scale Building Energy Efficiency Retrofit Program in Kuwait." Renewable and Sustainable Energy Reviews 50:1069-80. DOI: 10.1016/j.rser.2015.05.063

---. 2018. Optimal Design and Retrofit of Energy Efficient Buildings, Communities, and Urban Centers. Cambridge, MA: Butterworth-Heinemann, Elsevier.

Krarti, Moncef, Mohammad Aldubyan, and Eric Williams. 2020. "Residential Building Stock Model for Evaluating Energy Retrofit Programs in Saudi Arabia." Energy 195:116980. DOI: 10.1016/j. energy.2020.116980

Krarti, Moncef, and Alexandre Deneuville. 2015. "Comparative Evaluation of Optimal Energy Efficiency Designs for French and US Office Buildings." Energy and Buildings 93:332-44. DOI: 10.1016/j.enbuild.2015.01.046

Krarti, Moncef, Kankana Dubey, and Nicholas Howarth. 2017. "Evaluation of Building Energy Efficiency Investment Options for the Kingdom of Saudi Arabia." Energy 134:595-610. DOI: 10.1016/j. energy.2017.05.084

- - - 2019. "Energy Productivity Analysis Framework for Buildings: A Case Study of GCC Region." Energy 167:1251-65. DOI: 10.1016/j. energy.2018.11.060 
Lovins, Amory B. 1990. "The Negawatt Revolution." Across the Board 27(9):21-2.

Lu, Yuehong, Shengwei Wang, and Kui Shan. 2015. "Design Optimization and Optimal Control of Grid-connected and Standalone Nearly/Net Zero Energy Buildings." Applied Energy 155:463-77. DOI: 10.1016/j.apenergy.2015.06.007

Meyabadi, A. Fattahi, and Mohammad Hossein Deihimi. 2017. "A Review of Demand-side Management: Reconsidering Theoretical Framework." Renewable and Sustainable Energy Reviews 80:367-79. DOI: 10.1016/j. rser.2017.05.207

Ming, Zeng, Xue Song, Ma Mingjuan, Li Lingyun, Cheng Min, and Wang Yuejin. 2013. "Historical Review of Demand Side Management in China: Management Content, Operation Mode, Results Assessment and Relative Incentives." Renewable and Sustainable Energy Reviews 25:470-82. DOI: 10.1016/j.rser.2013.05.020

Navigant. 2019. Demand Side Management Overview: Energy Efficiency and Demand Response Market Analysis and Forecasts: 2019-2028. Boulder, CO: Navigant Research (now Guidehouse Insights).

PJM. 2009. "Reliability Pricing Model Demand Response and Energy Efficiency." http://www.pjm. com/ /media/markets-ops/rpm/20090406-dr-ee-inrpm-collateral.ashx

Russell, Christopher, Brendon Baatz, Rachel Cluett, and Jennifer Amann. 2015. Recognizing the Value of Energy Efficiency's Multiple Benefits. Washington, DC: American Council for an Energy-Efficient Economy.
Saudi Central Bank. 2019. "Economic Reports and Statistics, Saudi Arabian Monetary Authority, Yearly Statistics." Accessed June 17, 2020. http:// www.sama.gov.sa/en-US/EconomicReports/Pages/ YearlyStatistics.aspx

Saudi Electricity Company (SEC). 2020. "New Electricity Consumption Tariffs." Accessed January 15, 2019. https://www.se.com.sa/en-us/customers/ Pages/TariffRates.aspx

Strbac, Goran. 2008. "Demand Side Management: Benefits and Challenges." Energy Policy 36(12):4419-26. DOI: 10.1016/j.enpol.2008.09.030

Tuhus-Dubrow, Daniel, and Moncef Krarti. 2009. "Comparative Analysis of Optimization Approaches to Design Building Envelope for Residential Buildings." ASHRAE Transactions 115(2):205-219.

U.S. Energy Information Administration (EIA). 2019. Electric Power Annual 2018. Washington, DC: EIA. https://www.eia.gov/electricity/annual/pdf/epa.pdf

U.S. Environmental Protection Agency (EPA). 2010. Coordination of Energy Efficiency and Demand Response: A Resource for the National Action Plan for Energy Efficiency. Washington DC: EPA. https://www.epa.gov/sites/production/files/2015-08/ documents/ee_and_dr.pdf

Warren, Peter. 2014. "A Review of Demand-side Management Policy in the UK." Renewable and Sustainable Energy Reviews 29:941-51. DOI: 10.1016/j.rser.2013.09.009

- - - 2018. "Demand-side Policy: Global Evidence Base and Implementation Patterns." Energy and Environment 29(5):706-31. DOI: $10.1177 / 0958305 \times 18758486$ 
Wells, Louise, Behzad Rismanchi, and Lu Aye. 2018. "A Review of Net Zero Energy Buildings with Reflections on the Australian Context." Energy and Buildings 158:616-28. DOI: 10.1016/j. enbuild.2017.10.055
World Green Building Council (WGBC). 2013. The Business Case for Green Buildings: A Review of the Costs and Benefits for Developers, Investors and Occupants. London: WGBC. 


\section{Notes}




\section{About the Authors}

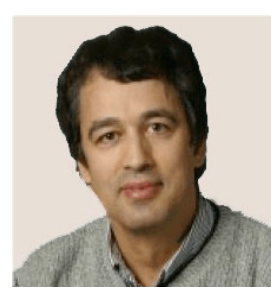

\section{Moncef Krarti}

Moncef is a visiting researcher with over 30 years of experience designing, testing, and assessing innovative energy efficiency and renewable energy technologies applied to buildings. He is a professor and coordinator of the Building Systems Program, Civil, Environment and Architectural Department at the University of Colorado.

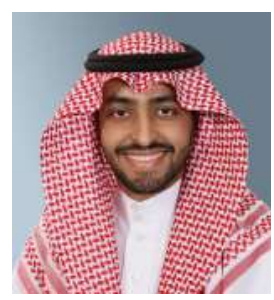

\section{Mohammad Aldubyan}

Mohammad is a researcher in KAPSARC's Climate and Environment program. His research focuses on energy efficiency, energy demand and price reforms. He is currently leading the Residential Energy Model (REEM), which simulates residential energy demand and estimates the impact of energy efficiency programs in Saudi Arabia's housing sector. He is also part of a project modeling energy demand in Saudi Arabia and estimating the economic impacts of energy price reforms.

Mohammad holds an M.Sc. in renewable and clean energy from the University of Dayton, Ohio and an M.Sc. in Econimics from Purdue University, West Lafayette.

\section{About the Project}

This study is part of the Modeling Residential Energy Demand and Energy Efficiency in Saudi Arabia project, which aims to accurately model the country's entire residential building stock. The project's key goals are (i) to better understand the current status of the Kingdom's housing sector in terms of its energy consumption, and (ii) to assess the potential of different energy efficiency programs and demand-response management to reduce electricity demand from the perspective of both households and the government. More broadly, the project aims to help KAPSARC conduct technical, economic, and environmental assessments of residential demand-side management options, and in turn to support policymakers seeking to design impactful energy strategies for Saudi Arabia's housing sector. 
INAPSARC

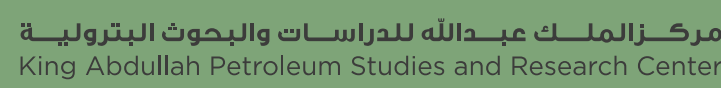

www.kapsarc.org 